\title{
Effect on Nutritional and Functional Characteristics by Encapsulating Rose canina Powder in Enriched Corn Extrudates
}

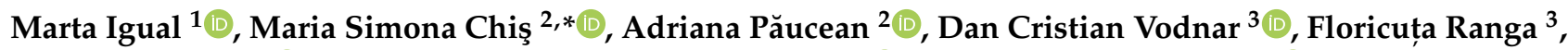 \\ Tania Mihăiescu ${ }^{4}\left(\mathbb{D}\right.$, Anamaria Iulia Török ${ }^{5}$, Anca Fărcaș ${ }^{2} \mathbb{D}$, Javier Martínez-Monzó ${ }^{1} \mathbb{( \mathbb { D }}$ \\ and Purificación García-Segovia ${ }^{1}[$ [
}

1 Food Investigation and Innovation Group, Food Technology Department, Universitat Politècnica de València Camino de Vera s/n, 46022 Valencia, Spain; marigra@upvnet.upv.es (M.I.); xmartine@tal.upv.es (J.M.-M.); pugarse@tal.upv.es (P.G.-S.)

2 Department of Food Engineering, Faculty of Food Science and Technology, University of Agricultural Sciences and Veterinary Medicine of Cluj-Napoca, 400372 Cluj-Napoca, Romania; adriana.paucean@usamvcluj.ro (A.P.); anca.farcas@usamvcluj.ro (A.F.)

3 Faculty of Food Science and Technology, Institute of Life Sciences, University of Agricultural Sciences and Veterinary Medicine of Cluj-Napoca, 400372 Cluj-Napoca, Romania; dan.vodnar@usamvcluj.ro (D.C.V.); floricuta.ranga@usamvcluj.ro (F.R.)

4 Department of Environment and Plant Protection, Faculty of Agriculture, University of Agricultural Sciences and Veterinary Medicine of Cluj-Napoca, 400372 Cluj-Napoca, Romania; tania.mihaiescu@usamvcluj.ro

5 NCDO-INOE 2000 Research Institute for Analytical Instrumentation, 67 Donath Street, 400293 Cluj-Napoca, Romania; iulia.torok@icia.ro

check for

updates

Citation: Igual, M.; Chiş, M.S.; Păucean, A.; Vodnar, D.C.; Ranga, F.; Mihăiescu, T.; Török, A.I.; Fărcaș, A.; Martínez-Monzó, J.; García-Segovia, P. Effect on Nutritional and Functional Characteristics by Encapsulating Rose canina Powder in Enriched Corn Extrudates. Foods 2021, 10, 2401. https://doi.org/10.3390/ foods10102401

Academic Editor: Markus Stieger

Received: 13 September 2021

Accepted: 6 October 2021

Published: 11 October 2021

Publisher's Note: MDPI stays neutral with regard to jurisdictional claims in published maps and institutional affiliations.

Copyright: (c) 2021 by the authors. Licensee MDPI, Basel, Switzerland. This article is an open access article distributed under the terms and conditions of the Creative Commons Attribution (CC BY) license (https:// creativecommons.org/licenses/by/ $4.0 /)$.
* Correspondence: simona.chis@usamvcluj.ro; Tel.: +40-264-596384

\begin{abstract}
Wild Rose canina fruit represents a rich source of bioactive compounds such as minerals, phenolic compounds, vitamins, carotenoids, folate, and antioxidant activity that still needs to be further exploited. Thus, this study aimed to use wild Rosa canina fruit encapsulated powder with different biopolymers aiming to manufacture ready-to-eat products, such as corn extrudates. To achieve this goal, extrudate physicochemical characteristics, such as water content $\left(\mathrm{x}_{\mathrm{w}}\right)$, water activity $\left(\mathrm{a}_{\mathrm{w}}\right)$, water absorption index (WAI), water solubility index (WSI), swelling index (SWE), hygroscopicity $(\mathrm{Hy})$, expansion index $(\mathrm{SEI})$, bulk density $\left(\rho_{\mathrm{b}}\right)$, porosity $(\varepsilon)$, textural, optical; nutritional; and functional analysis (phenolic acids, flavonoids, ascorbic and dehydroascorbic acids, vitamin C, carotenoids, folates, antioxidant activity, and minerals) were determined. Results highlighted that 4 and $8 \%$ addition of wild Rose canina fruit encapsulated powder could be successfully used in the corn extrudates, showing the positive influence on its nutritional and functional value. Strong positive Pearson correlations were identified between antioxidant capacity and total flavonoids, carotenoids, folates, and vitamin C of mixtures and extrudates Minerals increased their amount during the extrusion process, reaching the highest values at an addition of $8 \%$ rosehip encapsulated with pea protein biopolymer. Furthermore, from the biopolymers used in the present study, pea protein powder exhibited the highest protection on the analyzed bioactive compounds against the extrusion process.
\end{abstract}

Keywords: biopolymers; Rosa canina; corn extrudates

\section{Introduction}

The market for ready-to-eat products is constantly developing in the context of the social habits of the modern consumer. Furthermore, because of their sensorial features such as taste, texture, palatability, and appearance, ready-to-eat products are attractive to consumers [1,2].

The most common technique of producing ready-to-eat foods is extrusion cooking, the process of pressing the powder mixture through a die with a specific shape, which causes the material [3]. A wide range of food products could be produced with this technique, 
such as crisp expanded snacks, breakfast cereals, instant soups, meat analogs, and sports foods [4]. The main raw materials used for snack production by extrusion are cereals (e.g., corn and rice) due to their good expansion properties and enhancement of starch digestibility caused by gelatinization $[2,4]$. A recent review highlighted the possibility of incorporating pseudo-cereals, fruits, vegetables, legumes, pulses, oilseeds, roots, and tubers, nuts, and seeds to obtain value-added products [3].

Wild rose (Rosa canina L.) is a native shrub that belongs to the Rosaceae family and is widespread in northern Europe, Asia, Middle East, and North America. For centuries, the pseudo-fruits of Rosa canina (rose hips) are recognized as valuable food and medicine constituents due to their notable content of pro-health compounds [5]. The beneficial health effects are related to their rich content in flavonoids, carotenoids, fatty acids, vitamins, especially vitamin C, and folate [6].

A large body of literature has reported on the antioxidant, anti-inflammatory activities, antibacterial, antimutagenic, anti-diabetic, and anti-cancerogenic effects, as well as the capacity to balance the lipids level as well as the glucose content in blood [5,7-11]. The studies demonstrated that the compounds with antioxidant activity are polyphenols, vitamins C, E, B, and carotenoids known with synergistic effects [6,12].

The polyphenolic compounds include flavonoids: anthocyanins, procyanidins, catechin, quercetin, phenolic acids-gallic and ellagic acids-kaempferol, apigenin, and resveratrol, whereas the carotenoids found in rose hips are lycopene, $\beta$-carotene, and zeaxanthin [7]. Studies also reported high content of vitamin C and polyphenolics, especially quercetin, ellagic acid, gallic acid, and catechin in rose hips.

The addition of fruits into extruded products is considered a valuable way for the enhancement of the nutritional characteristics of extruded foods. However, the action of high-pressure temperature, combined with shear during extrusion leads to loss of sensitive nutritional compounds. In addition, several physicochemical factors could inactivate the bioactive compounds during food processing, storage, and digestion.

Thus, recent findings have investigated the ability of some polymers to allow the formulation of extruded foods with ingredients that require protection or stability; this approach extrusion could become a promising practice to deliver bioactive nutrients [3]. Moreover, recent findings report the use of biopolymers-comprising polysaccharides and proteins-to protect and deliver bioactive compounds [13].

Biopolymers act by forming matrices with bioactive compounds through molecular entanglement. Generally, it is considered that polysaccharides entrap the bioactives by surrounding the core, while proteins act like emulsifiers, swelling, and solubilization agents [14]. The most used polysaccharides are starch, dextrin, maltodextrin, cyclodextrin, alginate, pectin, cellulose, and gum. For proteins, non-allergic plant proteins extracted from pulses, cereals, or oilseeds using eco-friendly techniques have gained attention recently [15]. Several studies have reported the use of maltodextrin to encapsulate orange turpentine, tocopherol, and ascorbic acid using extrusion [16,17]. It was also reported that starch, mannose, and cyclodextrins could be used for the same purpose. However, maltodextrin is usually preferred because it is cheaper and ready to use [13]. Further, soy, pea, and chickpea protein-based matrices successfully encapsulated lycopene and folate $[18,19]$.

In the present study, biopolymers such as maltodextrin, pea protein powder, betacyclodextrin and resistant maltodextrin were used in rosehip manufacturing before the extrusion process. Rosehip addition in the final extrudates was $4 \%$ and $8 \%$ respectively. Thus, this study aims to evaluate the impact of enrichment with two quantities of Rosa canina rosehip powder encapsulated with different biopolymers, on nutritive and functional value, physicochemical properties, and extrusion parameters of extruded corn snacks.

\section{Materials and Methods}

\subsection{Standards and Reagents}

Acid ascorbic standard, carotene, and folic acid standards were purchased from SigmaAldrich (Steinheim, Germany) with a purity level $\geq 99.9 \% . \mathrm{H}_{2} \mathrm{O}_{2}, \mathrm{HNO}_{3}$, chlorogenic acid 
( $>98 \%$ HPLC), rutin (>99\% HPLC), gallic acid (>99\% HPLC), and Multi-elemental solutions of $1000 \mathrm{mg} \mathrm{L}^{-1}$ ICP Standard Certipur ${ }^{\circledR}$ were achieved from Merk, (Darmstadt, Germany). All other chemicals were purchased from the same supplier. A Millipore Direct-Q UV system from Merck (Darmstadt, Germany) was used to purified water.

\subsection{Raw Materials}

Corn grits (CM) were supplied by Maicerías Españolas S.L. (Valencia, Spain). Rosehip (R. canina) fruits were manually harvested in Aldehuela (Teruel, Spain) in September 2020. Maltodextrin (GLUCIDEX $\left.{ }^{\circledR} 12\right)(\mathrm{MD})$, pea protein powder (Nutralys ${ }^{\circledR}$ S85F) (PP), and beta-cyclodextrin (KLEPTOSE ${ }^{\circledR}$ ) (CD) were supplied by Roquette S.L. (Valencia, Spain). Resistant maltodextrin (Fibersol-2 ${ }^{\circledR}$ ) (RMD) was purchased from ADM/Matsutani, LLC (Decatur, IL, USA).

\subsection{Rosehip Powder Manufacturing}

Rose hips (1000 g) were washed with distilled water and homogenized in a Thermomix (TM 21, Vorwerk, Valencia, Spain) for $1 \mathrm{~min}$ at $5200 \mathrm{rpm}$. Then, distilled water (1000 g) was added and newly re-homogenized for $5 \mathrm{~min}$ at $5200 \mathrm{rpm}$. The mixture was filtered using a sieve (light of mesh diameter $1 \mathrm{~mm}$, Cisa 029077). Four different formulations were prepared by adding $10 \mathrm{~g}$ of MD, RMD, PP, or CD to $90 \mathrm{~g}$ of the filtered mixture. Moreover, a control sample $(\mathrm{R})$ without biopolymers was prepared. The formulated rosehip and control purees were then freeze-dried. A puree layer $(0.5 \mathrm{~cm}$ thickness) was placed in a standardized aluminum plate with the following dimensions: $15 \mathrm{~cm}$ diameter and $5 \mathrm{~cm}$ height. Consecutively, samples were stored at $-45^{\circ} \mathrm{C}$ (Vertical Freezer, CVF450/45, Ing. Climas, Barcelona, Spain) for $24 \mathrm{~h}$ before being dried in a Lioalfa-6 Lyophyliser (Telstar, Spain) at $2600 \mathrm{~Pa}$ and $-56.6^{\circ} \mathrm{C}$ for $48 \mathrm{~h}$. The freeze-dried samples were ground in a grinder (Minimoka, Taurus, Lleida, Spain) to obtain a free-flowing powder. Therefore, the powdered products obtained from rosehip were R (rosehip), MDR (maltodextrin rosehip), RMDR (resistant maltodextrin rosehip), PPR (pea protein rosehip), and CDR (cyclodextrin rosehip).

\subsection{Formulations and Extrusion Processing}

$\mathrm{CM}$ was mixed manually using a whisk, with two quantities (4 or $8 \%, 4 \mathrm{R}$, and $8 \mathrm{R}$ ) of obtained rosehip powders (R, MDR, RMDR, $P P R$, and CDR) to produce the extrusion mixtures (R4M, MDR4M, RMDR4M, PPR4M, CDR4M, R8M, MDR8M, RMDR8M, PPR8M, and CDR8M). The extrudates were coded as follows: R4M — extrudate with $4 \%$ rosehip addition, MDR4M — extrudate with maltodextrin rosehip 4\% addition, RMDR4M — extrudate with resistant maltodextrin $4 \%$ rosehip addition, PPR $4 \mathrm{M}$ — extrudate with pea protein $4 \%$ rosehip addition, CDR4M — extrudate with cyclodextrin $4 \%$ rosehip addition, R8M — extrudate with $8 \%$ rosehip addition, MDR8M-extrudate with maltodextrin rosehip $8 \%$ addition, RMDR8M — extrudate with resistant maltodextrin $8 \%$ rosehip addition, PPR8M-extrudate with pea protein $4 \%$ rosehip addition and CDR8M-extrudate with cyclodextrin $8 \%$ rosehip addition).

A single-screw laboratory extruder (Kompaktextruder KE 19/25; Brabender, Duisburg, Germany) was used for extrusion process. The total material extrusion amount was $200 \mathrm{~g}$. The operating conditions were: $3: 1$ compression ratio; $18 \mathrm{rpm}$ of dosing speed $(3.4 \mathrm{~kg} / \mathrm{h})$; $150 \mathrm{rpm}$ screw rotation; $25,70,170$, and $175{ }^{\circ} \mathrm{C}$ of temperature in barrel sections and $3 \mathrm{~mm}$ of the nozzle. The calculated specific mechanical energy of the corn extrusion ranged from 950 to $1100 \mathrm{~kJ} / \mathrm{kg}$. The pressure measured on the extruder head ranged between 92 and 127 bar. Extrudates were cooled at ambient temperature and sealed in plastic bags for further analysis. The extrudates obtained were: R4E, MDR4E, RMDR4E, PPR4E, CDR4E, R8E, MDR8E, RMDR8E, PPR8E, and CDR8E. 


\subsection{Analysis}

\subsubsection{Water Content and Water Activity}

Water content $\left(\mathrm{x}_{\mathrm{w}}\right)$ (g water/100 g sample) of mixtures and extruded was determined according to AOAC [20] in triplicate. Water activity $\left(\mathrm{a}_{\mathrm{w}}\right)$ of the extruded samples was measured by the AquaLab PRE LabFerrer equipment (Pullman, Washington, DC, USA).

\subsubsection{Expansion Index (SEI), Bulk Density $\left(\rho_{\mathrm{b}}\right)$ and Porosity $(\varepsilon)$}

The diameter of samples was measured for each sample with an electronic Vernier caliper (Comecta S.A., Barcelona, Spain). The surface expansion index of the die (SEI) was calculated as the quotient between the square of the measured diameters and the square of the die diameter [21]. $\rho_{\mathrm{b}}$ was calculated from the height and diameter of cylinders (extrudates samples) and then their weight was measured [21]. The porosity $(\varepsilon)$ was calculated according to García-Segovia et al. [21].

\subsubsection{Water Absorption Index (WAI), Water Solubility Index (WSI), and Swelling} Index (SWE)

WAI and WSI were determined by the method of Singh and Smith [22] and calculated according to Uribe-Wandurraga et al. [23]. SWE was measured using the bed volume technique expressed as $\mathrm{mm}$ of swollen sample per $\mathrm{g}$ of the dry initial sample [24].

\subsubsection{Hygroscopicity (Hy)}

Samples were placed in a petri dish at $25^{\circ} \mathrm{C}$, in an airtight plastic container containing $\mathrm{Na}_{2} \mathrm{SO}_{4}$ saturated solution ( $81 \%$ relative humidity). Initially and after 7 days each sample was weighed and the Hy was expressed as g of water gained per $100 \mathrm{~g}$ dry solids [25].

\subsubsection{Texture}

The average puncturing force $\left(\mathrm{F}_{\mathrm{p}}\right)$, the average specific force of structural ruptures $\left(\mathrm{F}_{\mathrm{s}}\right)$, the spatial frequency of structural ruptures $\left(\mathrm{N}_{\mathrm{sr}}\right)$, and crispness work $\left(\mathrm{W}_{\mathrm{c}}\right)$, and the number of peaks $\left(\mathrm{N}_{\mathrm{o}}\right)$ were obtained from the force-time curve of puncture test [26-28]. It was measured using a TA-XT2 Texture Analyzer (Stable Micro Systems Ltd., Godalming, UK) and software, Texture Exponent (version 6.1.12.0, Stable Micro Systems Ltd., Godalming, UK).

\subsubsection{Optical Properties}

Both translucency [29] and $\mathrm{CIE}^{*} L^{*} a^{*} b^{*}$ color coordinates were determined following the methodology described by García-Segovia et al. [21], considering standard light source D65 and a standard observer $10^{\circ}$ (Minolta spectrophotometer CM-3600d, Tokyo, Japan). Measurements of the extruded samples were taken 10 times. The total color differences of mixtures or extrudates with encapsulated rosehip powder $\left(\Delta \mathrm{E}_{1}\right)$ were calculated for the control sample. To evaluate the color changes of the mixtures because of extrusion, the total color difference $\left(\Delta \mathrm{E}_{2}\right)$ was calculated between each mixture and extruded at the same encapsulated rosehip powder addition.

\subsubsection{Samples Extraction Assisted by Ultrasounds}

For the phenolic compounds, a total amount of $0.5 \mathrm{~g}$ of each sample was homogenized with $2 \mathrm{~mL}$ of methanol and $1 \% \mathrm{HCl}$. The samples were mixed for $1 \mathrm{~min}$ with a vortex (Heidolph, Schwabach, Germany). Furthermore, the samples were sonicated for $30 \mathrm{~min}$ in an ultrasonic bath (Elmasonic E15H, Elma, Singen, Germany) and centrifugated (4000 $\times g$ for $10 \mathrm{~min}$ ) with a centrifuge Eppendorf 5804 (Eppendorf, Hamburg, Germany). Afterward, samples were filtered through a $0.45 \mu \mathrm{m}$ nylon filter (Millipore, Merck KGaA, Darmstadt, Germany) and injected into the HPLC system, according to our previous work, Igual et al. [30].

Ultrasound-assisted extraction for carotenoids was made according to Szabo et al. [31]. Shortly, $0.5 \mathrm{~g}$ of each sample was mixed with $5 \mathrm{~mL}$ mixture of methanol/ethyl:acetate/ petroleum:ether $(1: 1: 1, v / v / v)$, sonicated, and centrifuged $(5 \mathrm{~min}, 8000 \times g)$ using Eppendorf 5804 centrifuge (Eppendorf, Hamburg, Germany). After, a separation funnel was used for 
the supernatant collection. To obtain the sample's complete discoloration, the pellet was reextracted three more times, following the same procedure. Sodium chloride solution (15\%) was used to wash the collected extracts; then the organic phase was dried, and the solvent was eliminated by using an evaporator (Rotavapor R-124, Buchi, Flawil, Switzerland).

Ascorbic (AA) and dehydroascorbic (DHA) acids were analyzed by using ultrasoundassisted extraction. Shortly, $0.5 \mathrm{~g}$ of sample was mixed with $3 \mathrm{~mL}$ of $3 \% \mathrm{H}_{3} \mathrm{PO}_{4}$ and $8 \%$ acetic acid in an aqueous solution, sonicated for $30 \mathrm{~min}$ at $20^{\circ} \mathrm{C}$ (Elmasonic E15H) and centrifugated at $4000 \times g, 10 \mathrm{~min}, 4^{\circ} \mathrm{C}$ (Eppendorf). Afterward, after filtration, $20 \mu \mathrm{L}$ of each sample was injected into an HPLC system, according to our previous work [30].

For the folate extraction, $1 \mathrm{~g}$ of sample was mixed with $5 \mathrm{~mL}$ phosphate buffer $(\mathrm{pH}=7)$, sonicated in the ultrasonic bath for $30 \mathrm{~min}$, centrifuged at $4000 \times \mathrm{g}$, for $10 \mathrm{~min}$ and $24{ }^{\circ} \mathrm{C}$, filtered, and injected in the HPLC system, according to Igual et al. [30].

2.5.8. Phenolic Compounds Analysis through HPLC-DAD-ESI-MS (High-Performance Liquid Chromatography-Diode Array Detection-Electro-Spray Ionization Mass Spectrometry)

The method described in our previous work Igual et al. [30] was used for the identification and quantification of phenolic compounds. Analysis was determined by using an HP-1200 liquid chromatograph equipped with a quaternary pump, autosampler, DAD detector, and MS-6110 single-quadrupole API-electrospray detector (Agilent-Technologies, Santa Clara, CA, USA). The positive ionization mode was applied to detect the phenolic compounds; different fragmentor in the range 50-100 V, was applied. Eclipse XDB-C18 columns were used $(5 \mu \mathrm{m} ; 4.6 \times 150 \mathrm{~mm})$ from Agilent and the mobile phase was $(\mathrm{A})$ water acidified by acetic acid $0.1 \%(v / v)$ and $(\mathrm{B})$ acetonitrile acidified by acetic acid $0.1 \%$ $(99: 1, v / v)$ with the flow rate was $0.5 \mathrm{~mL} / \mathrm{min}$, following the elution program described by Dulf et al. [32]. The ESI (+) module was applied for MS fragmentation in the same parameters described above with a scan range of $100-1200 \mathrm{~m} / \mathrm{z}$.

Wavelengths of $\lambda=254,280$, and $340 \mathrm{~nm}$ were used for recording the chromatograms, and data acquisition was registered with the Agilent ChemStation software (Rev B.04.02 SP1, Palo Alto, CA, USA). The phenolics identification was based on UV-visible spectra, time retention, mass spectra, and chromatography with authentic standards (when available).

The quantification of flavonoids (flavones and isoflavones) was realized based on the rutin standard calibration curve $\left(y=26.935 x-33.784, r^{2}=0.9981\right)$ with a concentration ranged between 10-100 $\mu \mathrm{g} / \mathrm{mL}$ and expressed as equivalents of rutin ( $\mu \mathrm{g}$ rutin/g $\mathrm{g}_{\text {dry weight }}$ ), hydroxybenzoic acid was quantified using the calibration curve performed with gallic acid $\left(y=33.624 x+30.68, r^{2}=0.9978\right)$ on the concentration range of $1-100 \mu \mathrm{g} / \mathrm{mL}$ and expressed as gallic acid equivalents ( $\mu \mathrm{g}$ gallic acid $/ \mathrm{g}_{\mathrm{dry}}$ weight), and hydroxycinnamic acids (caffeic, syringic, p-coumaric acid, ferulic, Di-Caffeic) were quantified on the chlorogenic acid calibration curve $\left(y=22.585-36.728, \mathrm{r}^{2}=0.9937\right)$ with a minimum and maximum concentration of 10 to $50 \mu \mathrm{g} / \mathrm{mL}$ chlorogenic acid and expressed as chlorogenic equivalents $\left(\mu \mathrm{g}\right.$ chlorogenic acid $\left./ \mathrm{g}_{\text {dry weight }}\right)$. All the analyses were made in triplicate and are presented as means \pm standard deviations. The samples limit of quantification (LOQ) was $1 \mu \mathrm{g} / \mathrm{mL}$ and the limit of detection (LOD) was $0.125 \mu \mathrm{g} / \mathrm{mL}$.

\subsubsection{Carotenoids Analysis}

An Agilent 1200 HPLC system coupled to a diode array detector (Agilent-Technologies, Santa Clara, CA, USA), was used for the identification of carotenoids, as described by Szabo et al. [31]. Reversed-phase EC 250/4.6 Nucleodur 300-5 C-18 ec. column $(250 \times 4.6 \mathrm{~mm})$, $5 \mu \mathrm{m}$ (Macherey-Nagel, Düren, Germany) was used for carotenoid separation. The mobile phases were acetonitrile:water $(9: 1, v / v)$ with $0.25 \%$ triethylamine (A) and ethyl acetate with $0.25 \%$ triethylamine (B) with the elution program detailed described by Szabo et al. [31]. The flow rate was $1 \mathrm{~mL} / \mathrm{min}$, and the chromatograms were recorded at $\lambda=450 \mathrm{~nm}$. A $\beta$-Carotene calibration curve from Sigma-Aldrich (Steinheum, Germany) was used for the quantification of individual carotenoids $\left(y=86.781 x-19.028, r^{2}=0.9931\right)$, with a 
minimum and a maximum concentration of $1 \mu \mathrm{g} / \mathrm{mL}$ and $25 \mu \mathrm{g} / \mathrm{mL}$, respectively. The analysis was carried out in triplicate and presented as means \pm standard deviations.

\subsubsection{Ascorbic (AA) and Dehydroascorbic (DHAA) Acids Determination through} HPLC-DAD-ESI-MS

Ascorbic and dehydroascorbic acids were performed on an HPLC-DAD-ESI-MS system, composed of an Agilent 1200 HPLC equipped with a quaternary pump, autosampler, DAD detector, coupled to an MS-detector single-quadrupole Agilent 6110 (AgilentTechnologies, Santa Clara, CA, USA). The compounds separation was made on an XDB C18 Eclipse column $(4.5 \times 150 \mathrm{~mm}$, particle size $5 \mu \mathrm{m})$ with the following binary gradients: $1 \%$ formic acid:acetonitrile (95:5) in distilled water $(v / v)(\mathrm{A})$ and $1 \%$ formic acid in acetonitrile (B); the flow rate was $0.5 \mathrm{~mL} / \mathrm{min}$ at a temperature of $25 \pm 0.5^{\circ} \mathrm{C}$. A scanning range of $100-600 \mathrm{~m} / \mathrm{z}$ in the ESI (+) mode was performed for the MS fragmentation and the capillary voltage was set at $3000 \mathrm{~V}$, temperature $300^{\circ} \mathrm{C}$, with a nitrogen flow of $7 \mathrm{~L} / \mathrm{min}$. The spectral absorbance values were registered in the range $200-400 \mathrm{~nm}$ and the chromatograms were recorded at $\lambda 240 \mathrm{~nm}$. To acquire and analyze the samples, an Agilent ChemStation software (Rev B.04.02 SP1, Palo Alto, CA, USA) was used. Acid ascorbic standard was used for identification and quantification ( $\left.\mathrm{y}=95.421 \mathrm{x}-391.07, \mathrm{r}^{2}=0.0059\right)$. All samples were analyzed in triplicate and expressed as means \pm standard deviations.

\subsubsection{Folate Determination through HPLC-DAD-ESI-MS Assay}

The same HPLC-DAD-ESI-MS system described above was used for the folate determination. Briefly, the separation was performed on the XDB C18 Eclipse column $(4.5 \times 150 \mathrm{~mm}$, particle size $5 \mu \mathrm{m})$ with a mobile phase with acetonitrile:acetic acid $1 \%$ at a ratio of 20:80 $(\mathrm{v} / \mathrm{v})$ in the isocratic system, a flow rate of $0.5 \mathrm{~mL} / \mathrm{min}$, and temperature of $25 \pm 0.5^{\circ} \mathrm{C}$. A scanning range of $120-600 \mathrm{~m} / \mathrm{z}$ in the ESI $(+)$ mode was applied for the MS fragmentation and the following parameters were set for the capillary voltage: $3000 \mathrm{~V}$, temperature $350{ }^{\circ} \mathrm{C}$, and nitrogen flow at $7 \mathrm{~L} / \mathrm{min}$. Chromatograms were registered at wavelength $\lambda=280 \mathrm{~nm}$ and data acquisition was done by using Agilent ChemStation software (Rev B.04.02 SP1) as described in our previous work [30,33]. A folic standard curve $\left(\mathrm{y}=126.25 \mathrm{x}-16.283, \mathrm{r}^{2}=0.9945\right)$ with a minimum and maximum concentration of $1 \mu \mathrm{g} / \mathrm{mL}$ to $30 \mu \mathrm{g} / \mathrm{mL}$ was used. All the samples were analyzed in triplicate and the results were expressed as means \pm standard deviations.

\subsubsection{Antioxidant Capacity (AC)}

AC was determined using the free radical scavenging activity with the stable radical 2,2-diphenyl-1-picryl-hydrazyl-hydrate (DPPH) following Agudelo et al. [33] methodology in triplicate. Absorbance was measured at $515 \mathrm{~nm}$ with a UV-visible spectrophotometer (Helios Zeta, Thermo Electron Corporation, Loughborough, UK. The results were expressed as milligram Trolox equivalents (TE) per $100 \mathrm{~g}$ (mg TE/100 g).

\subsubsection{Minerals Determination}

Sample mineralization was conducted according to Mihăiescu et al. [34]. Briefly, $0.5 \mathrm{~g}$ of sample was homogenized with $\mathrm{HNO}_{3} 65 \%$ and $3 \mathrm{~mL} \mathrm{H}_{2} \mathrm{O}_{2}$, and mineralized in a Berghof MWS-2 (Berghof, Achalm, Germany), following the program parameters described by Mihăiescu et al. [34]. After, the samples were made up with ultrapure water to $25 \mathrm{~mL}$ volumetric flask. Furthermore, according to Senila et al. [35] the inductively coupled plasma optical emission spectrometry (ICP-OES) tool was used for sample analysis.

For analysis, s spectrometer Optima 5300DV (PerkinElmer, Waltham, MA, USA), with a dual viewing inductively coupled plasma optical emission coupled with CETAC 6000AT+ (CETAC, Omaha, NE, USA) ultrasonic nebulizer. The following parameters were used: $1300 \mathrm{~W}$ RF power, $15 \mathrm{~L} / \mathrm{min}$ plasma flow, $2.0 \mathrm{~L} / \mathrm{min}$ auxiliary flow, $0.8 \mathrm{~L} / \mathrm{min}$ nebulizer flow, and the sample uptake rate was $1.5 \mathrm{~mL} / \mathrm{min}$. The delay time for washing between each sample and signal measurement was $180 \mathrm{~s}$ and high-purity argon was used to sustain 
plasma as a carrier gas. For calibration, multi-elemental solutions of $1000 \mathrm{mg} / \mathrm{L} \mathrm{ICP}$ Standard Certipur ${ }^{\circledR}$ (Merck, Darmstadt, Germany) were used.

\subsection{Statistical Analysis}

To evaluate the data analysis of mixtures and extrudates, an ANOVA (Statgraphics Centurion XVII software) test with a confidence level of 95\% was used, $(p<0.05)$. The differences between means were evaluated through the Fisher test. Using Statgraphics Centurion XVII software (17.2.04 version, Statgraphics Technologies, Inc., The Plains, VA, USA) a high correlation analysis with a 95\% significance level was applied between the extrusion parameters and textual characteristics of extrudates. Pearson correlation was used to better explain the relationship between antioxidant activity and other bioactive compounds. All samples were analyzed in triplicate and the final results were reported as means \pm standard deviations.

\section{Results \& Discussions}

\subsection{Physicochemical Characteristics of Extrudates}

Mean values of $x_{w}, a_{w}, W A I, W S I, S W E, H y, S E I, \rho_{b}$, and $\varepsilon$ of extrudates are showed in Table 1. All rose hip enrichments studied provoked significant changes in $x_{W}, a_{W}$, WSI, Hy, and $\rho_{\mathrm{b}}$ with respect to control extruded $(p<0.05)$. When some of the rosehip powdered product was added $x_{w}, a_{w}$, and $\rho_{b}$ decreased significantly $(p<0.05)$, therefore, there are more hygroscopic and more easily soluble. The control sample presented $5.62(0.05) \mathrm{g}_{\mathrm{w}} / 100 \mathrm{~g}$, like other studies of corn extrudates [21,30] and the rest of the extrudates ranged from 3.7 to $4.6 \mathrm{~g}_{\mathrm{w}} / 100 \mathrm{~g}$. Extrusion moisture loss in the control was $10 \%$, like other studies [30]. However, extrusion moisture loss in enriched samples was $16-24 \%$. Thus, in samples with rose hip powder incorporation, as there is an increase in fiber, there is a greater amount of water to be absorbed by this component and, consequently, greater will be the loss of water at the open of the die with the pressure difference. According to Karkle et al. [36] it seems that the vapor pressure inside the air, extensibility, and waterbinding are strictly related to the moisture loss of the die. Furthermore, its emphasized the starch degree transformation, since the presence of ungelatinized starch decrease extensibility degree, meanwhile residual water is shut in the structure, rather than evaporating at vapor flashpoint. The values of $\mathrm{a}_{\mathrm{w}}$ were similar to the other corn snacks obtained by García-Segovia et al. and Uribe-Wandurraga et al. [21,23]. The lowest $\mathrm{a}_{\mathrm{w}}$ values were obtained in PPR4E and CDR4E.

WAI and WSI properties exhibit the interaction of extrudates with water. [37]. WAI shows the quantity of water absorbed by the extrudate when immersed in water [38], meanwhile, WSI could emphasize the molecular damage that can occur during extrusion due to the water solubilized components releasing [39]. As observed in Table 1, RMDR4E and RMDR8E showed the lowest WAI values, meanwhile, the WSI parameter registered the highest extended values Using MD, RMD, and CD for encapsulating rosehip significantly increased WSI values $(p<0.05)$. Furthermore, according to the soluble nature of these biopolymers, extrudates with $\mathrm{MD}, \mathrm{RMD}$, and $\mathrm{CD}$ presented water solubilized components that make them vulnerable to molecular damage. Samples with PP or without biopolymers presented WSI values lower than the other extruded samples. Thus, R4E, R8E, PPR4E, and PPR8E could be more stable samples. SWE mean values expressed as $\mathrm{mL}_{\text {swollen }} / \mathrm{g}_{\text {dry }}$ solid are also shown in Table 1. Extrudates with PP in the formulation significantly presented the highest values of SWE $(p<0.05)$, probably for the hydration of the protein structure. However, extrudates with CD in the formulation presented the lowest values; the control SWE was like other studies $[23,30]$. Adding rosehip powders in this study provoked an increase of Hy, most in RMDR4E. 


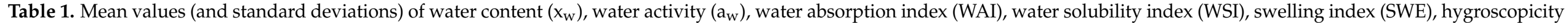
$(\mathrm{Hy})$, expansion index (SEI), bulk density $\left(\rho_{\mathrm{b}}\right)$ and porosity $(\varepsilon)$ of extrudates.

\begin{tabular}{|c|c|c|c|c|c|c|c|c|c|}
\hline Sample & $\begin{array}{c}x_{w} \\
\left(g_{w} / 100 g\right)\end{array}$ & $a_{w}$ & WAI & WSI (\%) & $\begin{array}{c}\mathrm{SWE} \\
\left(\mathrm{mL}_{\text {swollen }} / \mathrm{g}_{\text {dry solid }}\right)\end{array}$ & $\begin{array}{c}\text { Hy } \\
\left(\mathrm{g}_{\mathrm{w}} / 100 \mathrm{~g}_{\text {dry solid }}\right)\end{array}$ & SEI & $\begin{array}{c}\rho_{\mathrm{b}} \\
\left(\mathrm{g} / \mathrm{cm}^{3}\right)\end{array}$ & $\varepsilon(\%)$ \\
\hline $\mathrm{CE}$ & $5.62(0.05)^{\mathrm{a}}$ & $0.327(0.003)^{\mathrm{a}}$ & $4.135(0.015)^{b}$ & $16.81(0.12)^{g}$ & $2.279(0.102)^{\mathrm{e}}$ & $21.69(0.19)^{f}$ & $13.1(0.4)^{f}$ & $0.103(0.003)^{a}$ & $91.3(0.2)^{\mathrm{cd}}$ \\
\hline $\mathrm{R} 4 \mathrm{E}$ & $4.35(0.05) b c d$ & $0.310(0.003)^{b}$ & $3.9(0.2) \mathrm{cd}$ & $20.3(0.9)$ de & $2.59(0.04) \mathrm{cd}$ & $23.8(0.3) b c$ & $13.9(0.4)^{\mathrm{d}}$ & $0.078(0.004)^{\mathrm{d}}$ & $93.0(0.4)^{\mathrm{a}}$ \\
\hline RMDR4E & $4.565(0.005)^{b}$ & $0.303(0.003)^{\mathrm{c}}$ & $3.246(0.015)^{h}$ & $26.21(0.13)^{a}$ & $2.576(0.004)^{\mathrm{cd}}$ & $25.1(0.2)^{\mathrm{a}}$ & $15.6(0.4)^{\mathrm{a}}$ & $0.0795(0.0004)^{b c d}$ & $93.074(0.009)^{\mathrm{a}}$ \\
\hline PPR4E & $4.1(0.2)$ de & $0.259(0.003)^{h}$ & $3.630(0.012)^{\text {efg }}$ & $20.95(0.12)^{d}$ & $4.7(0.3)^{b}$ & $22.71(0.14)$ de & $14.6(0.6)^{c}$ & $0.081(0.006)^{b c d}$ & $91.9(0.5)^{b c}$ \\
\hline CDR4E & $4.10(0.03)^{\mathrm{de}}$ & $0.258(0.003)^{h}$ & $3.775(0.006)$ cde & $23.32(0.02)^{b}$ & $1.70(0.17)^{\mathrm{fg}}$ & $22.3(0.7){ }^{\text {ef }}$ & $15.1(0.4)^{b}$ & $0.090(0.009)^{b}$ & $92.3(0.6)^{a b}$ \\
\hline R8E & $4.0(0.3)^{\mathrm{e}}$ & $0.274(0.003)^{g}$ & $4.48(0.02)^{a}$ & $18.51(0.17)^{\mathrm{f}}$ & $2.674(0.012)^{c}$ & $23.5(0.6)^{b c}$ & $12.4(0.4)^{\mathrm{g}}$ & $0.084(0.002)^{b c d}$ & $90.8(0.3)^{d}$ \\
\hline RMDR8E & $4.34(0.06)^{b c d}$ & $0.300(0.003) \mathrm{cd}$ & $3.56(0.03)^{g}$ & $25.8(0.2)^{a}$ & $2.34(0.14)$ de & $22.41(0.08)^{e}$ & $14.1(0.3)^{d}$ & $0.079(0.009)^{\mathrm{cd}}$ & $92.3(0.2)^{a b}$ \\
\hline PPR8E & $3.70(0.09)^{\mathrm{f}}$ & $0.278(0.003)^{f}$ & $3.882(0.003)^{c}$ & $19.5(0.4)^{\mathrm{e}}$ & $5.68(0.17)^{\mathrm{a}}$ & $23.2(0.2) \mathrm{cd}$ & $14.2(0.3)^{d}$ & $0.075(0.004)^{d}$ & $92.6(0.4)^{a b}$ \\
\hline CDR8E & $4.26(0.05)$ cde & $0.290(0.003)^{\mathrm{e}}$ & $3.61(0.05) \mathrm{fg}$ & $24.0(0.3)^{b}$ & $1.681(0.108)^{g}$ & $23.37(0.03)^{\mathrm{cd}}$ & $13.5(0.2)^{\mathrm{e}}$ & $0.0861(0.0009)^{b c d}$ & $92.02(0.12) b c$ \\
\hline
\end{tabular}

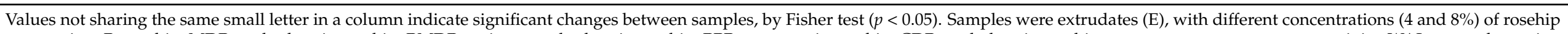

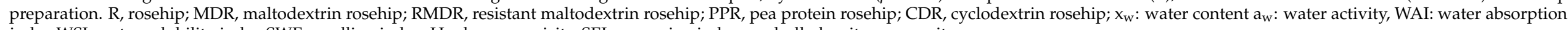
index WSI: water solubility index SWE: swelling index, Hy: hygroscopicity, SEI: expansion index, $\rho_{b}$ : bulk density, $\varepsilon$ : porosity 
Typical extrudate structures are due to the sudden expansion—at the exit—of the molten mass from the restricted die, from high pressure to atmospheric pressure [26]. Adding rosehip powders to extrusion mixtures increased the SEI values, except for R8E, which showed a slight SEI decreased than the control (Table 1). The significantly highest SEI values were found in MDR4E and RMDR4E. There was a significant Pearson correlation between SEI and WAI $(-0.7385, p<0.05)$. Other studies have reported the same link between these parameters [28,30]. High WSI values are related to molecular damage due to the ease of solubilization of a sample so, according to our results, samples with PP or without biopolymers presented WSI values lower than the other extruded samples therefore more stability.

Finally, Table 1 also includes $\rho_{\mathrm{b}}$ and $\varepsilon$ of extrudates. Density is defined as a general extrudate property, that could indicate changes in material parameters such as cell structure, pores, and voids developed during the extrusion process; a porous structure is characterized by highly expanded extruded materials [40]. This porous structure was measured by $\varepsilon$. There were significant $(p<0.05)$ differences in $\rho_{\mathrm{b}}$ values between control and enriched samples, with the values of the control $\rho_{\mathrm{b}}$ being higher. $\rho_{\mathrm{b}}$ was related to $\mathrm{x}_{\mathrm{w}}$ by significant Pearson correlation $(0.7311, p<0.05)$ as also shown by García-Segovia et al. [21]. $\varepsilon$ values ranged from 90.8 to 93.1 . This is a narrow range, and $\varepsilon$ did not show a clear trend. The highest $\varepsilon$ values were observed in R4E and RMDR4E; however, PPR8E, RMDR8E, and CDR4E also showed significant values higher than the control $(p<0.05) . \rho_{\mathrm{b}}$ and $\varepsilon$ values of the control sample were like other corn extrudates $[23,30]$.

Texture characteristics are included in Table 2. Texture is defined as one of the main characteristics of extruded snacks with a high influence on the final quality of food products [41]. The extruded snack products texture is characterized mainly by crunchiness and crispness [42]. $\mathrm{W}_{\mathrm{c}}$ is described as the force applied on the first bite to break the sample [43] and could correlate to fracturability, as a sensory criterion [44].

Table 2. $\mathrm{W}_{\mathrm{c}}, \mathrm{N}_{\mathrm{sr}}, \mathrm{F}_{\mathrm{s}}, \mathrm{F}_{\mathrm{p}}$, and $\mathrm{N}_{0}$ extrudates mean values (and standard deviations).

\begin{tabular}{|c|c|c|c|c|c|}
\hline Sample & $\mathbf{W}_{\mathrm{c}}(\mathbf{N} \times \mathbf{m m})$ & $N_{s r}\left(m^{-1}\right)$ & $F_{s}(N)$ & $F_{p}(N)$ & $\mathbf{N}_{0}$ \\
\hline $\mathrm{CE}$ & $0.20(0.03)^{\mathrm{a}}$ & $10.1(0.9)^{b c}$ & $2.1(0.3)^{\mathrm{a}}$ & $1.6(0.2)^{\mathrm{a}}$ & $106(8)^{d}$ \\
\hline $\mathrm{R} 4 \mathrm{E}$ & $0.12(0.03)^{b c}$ & $11.1(1.6)^{b c}$ & $1.3(0.3)^{b c d}$ & $1.0(0.2)^{b c}$ & $123(14)^{b c d}$ \\
\hline MDR4E & $0.13(0.04)^{b}$ & $11.5(1.9)^{\mathrm{b}}$ & $1.4(0.2)^{b}$ & $1.0(0.3)^{b}$ & $126(21) b c$ \\
\hline RMDR4E & $0.21(0.05)^{\mathrm{a}}$ & $10.7(1.2)^{b c}$ & $2.5(0.5)^{\mathrm{a}}$ & $1.1(0.2)^{b}$ & $127(14)^{b c}$ \\
\hline PPR4E & $0.099(0.013)^{\mathrm{cd}}$ & $11.61(1.02)^{b}$ & $1.4(0.3)^{b}$ & $0.9(0.2)^{b c}$ & $137(7)^{\mathrm{ab}}$ \\
\hline CDR4E & $0.110(0.013) b c$ & $10.0(0.8)^{\mathrm{c}}$ & $1.09(0.08)$ cde & $0.77(0.06)^{\mathrm{cd}}$ & $115(5)^{\mathrm{cd}}$ \\
\hline R8E & $0.060(0.004)^{\mathrm{e}}$ & $10.8(1.4)^{b c}$ & $0.728(0.102)^{f}$ & $0.48(0.05)^{\mathrm{e}}$ & $121(14)^{b c d}$ \\
\hline MDR8E & $0.097(0.016)^{\mathrm{cd}}$ & $14.0(1.2)^{\mathrm{a}}$ & $1.34(0.19) b c$ & $1.1(0.2) b c$ & $145(14)^{\mathrm{a}}$ \\
\hline RMDR8E & $0.095(0.017)^{\mathrm{cd}}$ & $11.04(1.02) b c$ & $1.05(0.19)$ de & $0.73(0.17)^{d}$ & $125(8) b c$ \\
\hline PPR8E & $0.075(0.007)$ de & $13.12(0.12)^{\mathrm{a}}$ & $1.04(0.04) \mathrm{de}$ & $0.77(0.09)^{\mathrm{cd}}$ & $134(15)^{a b}$ \\
\hline CDR8E & $0.078(0.003)$ de & $11.0(1.2) b c$ & $0.85(0.06)^{\text {ef }}$ & $0.62(0.13) \mathrm{de}$ & $127(19) b c$ \\
\hline
\end{tabular}

Values not sharing the same small superscript letter in a column indicate significant changes between samples, by Fisher test $(p<0.05)$. Samples were extrudates (E), with different concentrations ( 4 and $8 \%$ ) of rosehip preparation. R, rosehip; MDR, maltodextrin rosehip; RMDR, resistant maltodextrin rosehip; PPR, pea protein rosehip; CDR, cyclodextrin rosehip; crispness work (Wc), the spatial frequency of structural ruptures (Nsr), the average specific force of structural ruptures $(\mathrm{Fs})$, average puncturing force $(\mathrm{Fp})$, and several peaks $\left(\mathrm{N}_{0}\right)$ of extrudates.

Hardness and chewing are usually associated with $\mathrm{F}_{\mathrm{p}}$ and $\mathrm{F}_{\mathrm{s}}$ of extruded products. Hardness is defined as the necessary force to compress a solid substance between the molar teeth [40]. $\mathrm{N}_{\mathrm{sr}}$ describes the number of fracture events during puncture [45] and $\mathrm{N}_{0}$ corresponds to the number of fractures throughout the test [44]. Adding of rosehip powders studied to mixtures to extrusion decreased $W_{c}$ values except to RMDR4E. The significantly lowest $W_{c}$ value was found in R8E. Samples with rosehip powders required less force in the first bite to break the extrudate. All extrudates with rosehip powders showed lower $F_{p}$ values than control and lower $F_{s}$ values too, except to RMDR4E which presented similar $\mathrm{F}_{\mathrm{S}}$ than control. $\mathrm{N}_{0}$ was significantly higher in extrudates with rosehip 
powders in comparison with control. $\mathrm{N}_{\mathrm{sr}}$ and $\mathrm{N}_{0}$ are associated with the crunchiness of extruded snacks [21]; in this study, the use of rosehip powders in mixtures to obtain snacks made that extrudates were crunchier. Authors mentioned that $\mathrm{N}_{\mathrm{sr}}$ and $\mathrm{N}_{0}$ could be influenced by the pore size, and furthermore, could be related to the interface fractures propagation, according to Chanvrier et al. [46].

Correlation analysis was applied in order to better explain the relationship between texture parameters of extruded products and typical extrudate parameters; $\mathrm{W}_{\mathrm{c}}$ was positively correlated with $\mathrm{x}_{\mathrm{W}}(0.7175, p<0.05)$ and $\mathrm{F}_{\mathrm{p}}$ with $\mathrm{x}_{\mathrm{W}}$ and $\rho_{\mathrm{b}}$ presenting values of Pearson correlation of $0.7870(p<0.05)$ and $0.6315(p<0.05)$, respectively. Other works with corn snacks also detected a significant positive correlation between $\mathrm{F}_{\mathrm{p}}$ and $\rho_{\mathrm{b}}$ [30].

Mixtures and extrudates optical properties are showed in Table $3\left(L^{*}, a^{*}, b^{*}, \mathrm{C}^{*}, \mathrm{~h}^{*}, \Delta \mathrm{E}_{1}\right.$, and $\Delta \mathrm{E}_{2}$ ). Both mixtures and extrudates with or without $\mathrm{R}$ did not show differences in the measurements taken on white and black backgrounds; therefore, they were not translucent and color coordinates $\mathrm{CIE}^{*} L^{*} a^{*} b^{*}$ and the values of chroma $\left(\mathrm{C}^{*}\right)$ and tone $\left(\mathrm{h}^{*}\right)$ were obtained directly from the equipment used for color measurement. This has also been observed in corn snacks previously [30]. In contrast, other studies [21,28] have shown differences in those measurements (white and black backgrounds) in corn extrudates. In the present study, rosehip powder addition had a negative influence on $L^{*}$ and $h^{*}$ parameters $(p<0.05)$ but a positive one regarding the $a^{*}$ value.

All mixtures were redder by the addition of rosehip or encapsulated rosehip. Moreover, these extrudates were also significantly $(p<0.05)$ redder than CE. R8M showed the highest $a^{*}$ and the lowest $L^{*}$. The lowest values of $b^{*}$ and $C^{*}$ were in PPR4M and the highest values were in RMDR8M. After extrusion, $L^{*}, a^{*} b^{*}$, and $C^{*}$ decreased significantly $(p<0.05)$. R8E presented the significantly $(p<0.05)$ highest values of $a^{*}, b^{*}$, and $C^{*}$; however, the lowest $\mathrm{h}^{*}$ was for PPR8. Moreover, CDR8E showed the significantly $(p<0.05)$ lowest value of $L^{*}$. These differences can be observed in Figure 1.

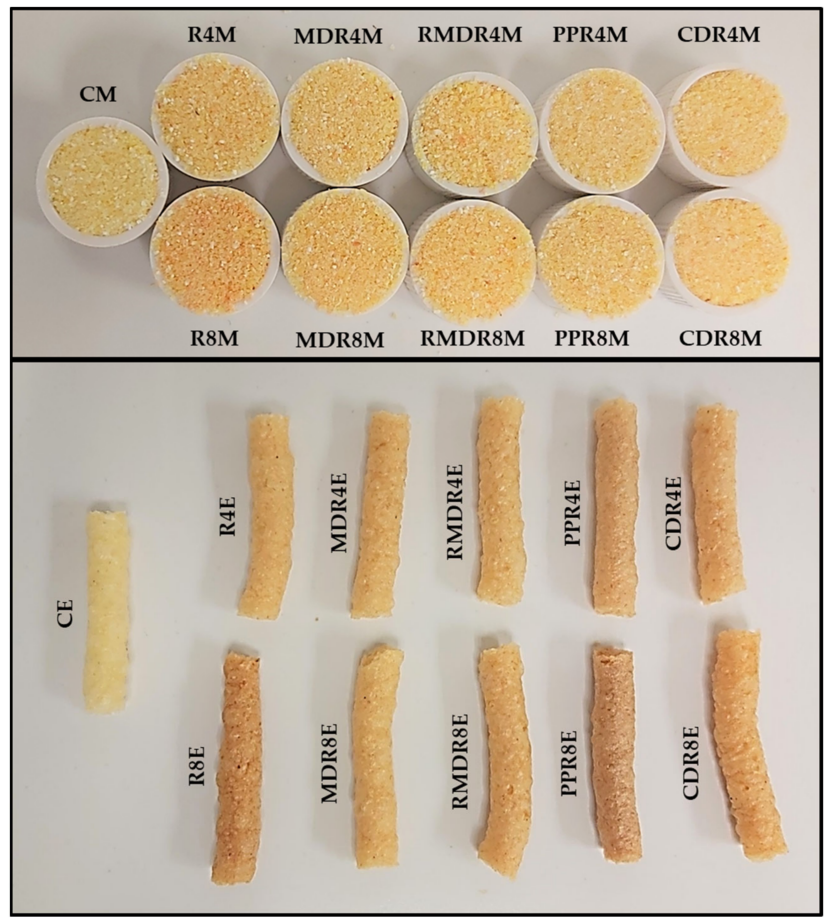

Figure 1. Mixtures (M) and extrudates (E) with different concentrations (4 and 8\%) of rosehip preparation. R, rosehip; MDR, maltodextrin rosehip; RMDR, resistant maltodextrin rosehip; PPR, pea protein rosehip; CDR, cyclodextrin rosehip. 
Table 3. Color coordinates $\left(L^{*}, a^{*}, b^{*}, \mathrm{C}^{*}\right.$, and $\left.\mathrm{h}^{*}\right)$ and total color differences $(\Delta \mathrm{E})$ of corn mixtures and extrudates.

\begin{tabular}{|c|c|c|c|c|c|c|c|}
\hline Parameter & $L^{*}$ & $a^{*}$ & $b^{*}$ & $\mathrm{C}$ & $\mathbf{H}$ & $\Delta \mathrm{E}_{1}$ & $\Delta \mathrm{E}_{2}$ \\
\hline & & & & Mixtures & & & \\
\hline $\mathrm{CM}$ & $79.9(0.6)^{\mathrm{aA}}$ & $6.4(0.5) \mathrm{gA}$ & $41(3)^{a b c A}$ & $42(3)^{\mathrm{cA}}$ & $81.1(0.3)^{a B}$ & - & - \\
\hline $\mathrm{R} 4 \mathrm{M}$ & $74.4(0.2) \mathrm{dA}$ & $13.4(0.6) \mathrm{cA}$ & $40.4(0.5) \mathrm{bcA}$ & $42.6(0.3) \mathrm{bcA}$ & 71.59 (1.02) gB & $8.9(0.7) \mathrm{cA}$ & - \\
\hline MDR4M & $76.7(0.2)^{\mathrm{cA}}$ & $11.0(0.2) \mathrm{eA}$ & $41.0(1.6)$ bcA & $42.4(1.6){ }^{\mathrm{cA}}$ & $75.0(0.3)^{\mathrm{cdA}}$ & $5.7(0.2) \mathrm{dB}$ & - \\
\hline RMDR4M & $76.3(0.5)^{\mathrm{cA}}$ & $11.6(0.3)^{\mathrm{deA}}$ & $41.2(1.5)^{\mathrm{abcA}}$ & $42.8(1.4)^{\mathrm{bcA}}$ & $74.3(0.7) \mathrm{deB}$ & $6.4(0.4) \mathrm{dA}$ & - \\
\hline PPR4M & $76.2(0.2)^{\mathrm{cA}}$ & $9.7(0.2) \mathrm{fA}$ & $36.9(0.8) \mathrm{dA}$ & $38.1(0.7) \mathrm{dA}$ & $75.2(0.5){ }^{\mathrm{cA}}$ & $6.5(0.6) \mathrm{dB}$ & - \\
\hline CDR4M & $77.4(0.4)^{\mathrm{bA}}$ & $9.6(0.6)^{\mathrm{fA}}$ & $42.4(1.4)^{\mathrm{abA}}$ & $43.5(1.5)$ abcA & $77.2(0.4) \mathrm{bA}$ & 4.39 (1.09) eB & - \\
\hline $\mathrm{R} 8 \mathrm{M}$ & $71.0(0.3)^{\mathrm{fA}}$ & $15.8(0.8)^{\mathrm{aA}}$ & $40(2) \mathrm{cA}$ & $43(2)$ abcA & $68.5(0.8) \mathrm{hA}$ & $13.0(0.6)^{\mathrm{aA}}$ & - \\
\hline MDR8M & $73.8(0.5)^{\mathrm{eA}}$ & $14.2(0.3){ }^{\mathrm{bB}}$ & $42.5(1.7)^{\mathrm{abB}}$ & $44.8(1.7)^{a b B}$ & $71.5(0.4)^{\mathrm{gB}}$ & $10.1(0.8)$ bA & - \\
\hline RMDR8M & $74.5(0.7) \mathrm{dA}$ & $13.1(0.6)^{\mathrm{cA}}$ & $43.3(1.4)^{\mathrm{aA}}$ & $45.2(1.5)^{\mathrm{aA}}$ & $73.1(0.6)^{\mathrm{fA}}$ & $9.0(0.9)^{\mathrm{cA}}$ & - \\
\hline PPR8M & $73.6(0.8)^{\mathrm{eA}}$ & $10.2(0.4)^{\mathrm{fA}}$ & $37.7(0.9) \mathrm{dA}$ & $39.06(1.03) \mathrm{dA}$ & $74.9(0.3)^{\mathrm{cdA}}$ & $8.1(0.4)^{\mathrm{cB}}$ & - \\
\hline \multirow[t]{2}{*}{ CDR8M } & $76.6(0.3)^{\mathrm{cA}}$ & $11.68(0.08) \mathrm{dA}$ & $40.75(1.03) \mathrm{bcA}$ & $42.4(0.9)^{\mathrm{cA}}$ & $74.0(0.4) \mathrm{eA}^{\mathrm{eA}}$ & $6.3(0.3) \mathrm{dB}$ & - \\
\hline & & & & Extrudates & & & \\
\hline $\mathrm{CE}$ & $56(2) a \mathrm{aB}$ & $0.148(0.013)^{\mathrm{gB}}$ & $17.9(0.7) \mathrm{eB}$ & $17.9(0.7) \mathrm{eB}$ & $89.53(0.03)^{\mathrm{aA}}$ & - & $34(2) a b c$ \\
\hline R4E & $52(2) \mathrm{bcdB}$ & $5.6(0.6) \mathrm{deB}$ & $21.0(0.6)^{b c B}$ & $21.7(0.7) \mathrm{bcdB}$ & $75.2(1.2) \mathrm{cdA}$ & $7.4(1.8) \mathrm{deA}$ & $30.75(1.03) \mathrm{cd}$ \\
\hline MDR4E & $52(3) \mathrm{bcB}$ & $5.3(0.7)$ efB & $20.8(2.3) \mathrm{bcB}$ & $21(2)$ bcdB & $75.6(0.9) \mathrm{bcA}$ & $7.5(1.5) \mathrm{deA}$ & $32(3)$ bcd \\
\hline RMDR4E & $55(2)$ abB & $4.7(0.3) \mathrm{fB}$ & $20.0(1.8)^{b c d B}$ & $20.6(1.8) \mathrm{cdB}$ & $76.7(0.9)^{\mathrm{bA}}$ & $5.7(0.5) \mathrm{eA}$ & $31(3)^{b c d}$ \\
\hline CDR4E & $48.6(1.4) \mathrm{deB}$ & $5.2(0.5)^{\mathrm{efB}}$ & $19.3(0.6)^{\mathrm{cdeB}}$ & $20.0(0.7)^{\mathrm{cdeB}}$ & $74.9(1.3)^{\mathrm{cdB}}$ & $9.0(1.5)^{\mathrm{cdA}}$ & $37.12(1.08)^{a}$ \\
\hline $\mathrm{R} 8 \mathrm{E}$ & $50.1(0.9)$ cdeB & $10.3(0.5)^{\mathrm{aB}}$ & $24.8(0.5)^{\mathrm{aB}}$ & $26.8(0.6)^{\mathrm{aB}}$ & $67.5(0.6) \mathrm{gA}$ & $13.5(0.7)^{\mathrm{aA}}$ & $26.6(0.8)^{\mathrm{e}}$ \\
\hline MDR8E & $54.0(1.5)^{\mathrm{abB}}$ & $6.3(0.8)^{\mathrm{cdB}}$ & $22.0(1.4)^{\mathrm{bB}}$ & $22.9(1.6)^{b B}$ & $74.04(1.06) \mathrm{deA}$ & $7.8(1.6)^{\mathrm{deB}}$ & $29.5(1.4)$ de \\
\hline RMDR8E & 49 (2) deB & $6.8(0.4) \mathrm{bcB}$ & $21.07(1.04) \mathrm{bcB}$ & $22.13(1.09)$ bcB & $72.2(0.4)^{\mathrm{fA}}$ & $10.4(1.3)^{b c A}$ & $35(2) \mathrm{ab}$ \\
\hline PPR8E & $49.8(1.3)$ cdeB & $7.3(0.7) \mathrm{bB}$ & 18.3 (1.3) deB & 19.7 (1.4) deB & $68.3(0.9) \mathrm{gB}$ & $9.5(0.8) \mathrm{bcdA}$ & $30.9(1.7)^{\mathrm{cd}}$ \\
\hline CDR8E & $48(4) \mathrm{eB}^{\mathrm{eB}}$ & $6.6(0.5) \mathrm{bcB}$ & $20(2)$ bcdB & $21(2)$ bcdB & $71.7(0.7) \mathrm{fB}$ & $11.3(2.8) \mathrm{bA}$ & $36(4)^{a}$ \\
\hline
\end{tabular}

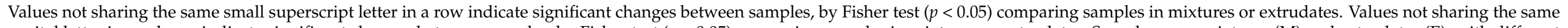

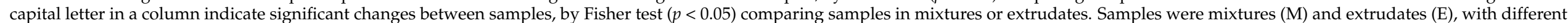
concentrations (4 and $8 \%$ ) of rosehip preparation. R, rosehip; MDR, maltodextrin rosehip; RMDR, resistant maltodextrin rosehip; PPR, pea protein rosehip; CDR, cyclodextrin rosehip. 
Total color differences between samples with rosehip and the control $\left(\Delta \mathrm{E}_{1}\right)$ ranged between 4.4 and 13.5, higher than 3 units; therefore, humanly perceptible [47]. Color is an important quality parameter because it reflects the extent of chemical reactions and the degree of cooking or degradation that takes place during the extrusion process. $\Delta \mathrm{E}_{2}$ represents the total color difference between extrudates and mixtures. According to Dogan et al. [48] extrusion provokes darker products with more intense yellow and red colors. In this study, $\Delta \mathrm{E}_{2}$ ranged between 26.6 and 37.1. These $\Delta \mathrm{E}_{2}$ values were significantly higher in CDR4E than in the other extrudates and lower in R8E compared to the rest.

Figure 1 shows the appearance of the mixtures and extrudates. In similarity with color coordinates, the reddish color ( $a^{*}$ increase) of the mixture with increasing rose hip addition is remarkable. Moreover, extrudates lost the reddish color compared to mixtures, as observed in $\Delta \mathrm{E}_{2}$. The appearance of the extrudates is adequate and in the same trend as these products.

\subsection{Nutritional and Functional Value of Mixtures and Extrudates \\ 3.2.1. Phenolic Acid Profile of Mixtures and Extrudates}

The mixtures and extrudate phenolic acids content are presented in Table 4. The cornflour used in this study highlighted a total phenolic acid of $160.57 \mu \mathrm{g} / \mathrm{g}$, from which the main amounts were represented by $\mathrm{p}$-Coumaric, Di-caffeic, and ferulic acids with values $58.61,42.52$, and $29.34 \mu \mathrm{g} / \mathrm{g}$, respectively, whereas caffeic and syringic acids registered smaller values, 17.27 and $12.82 \mu \mathrm{g} / \mathrm{g}$, respectively. The rosehip total phenolic amount was low compared with the corn flour and exhibited a value of only $27.09 \mu \mathrm{g} / \mathrm{g}$, from which only ferulic and p-Coumaric acids were identified with values of 9.03 and $18.06 \mu \mathrm{g} / \mathrm{g}$, respectively. The small amount of rosehip phenolic acids could be explained by rosehip being rich in chlorogenic acids and catechin, as previously shown by Tabaszewska et al. [7], acids not identified in this study.

Table 4. Main phenolic acids (p-Courmatic acid, ferulic acid, Di-caf, expressed in $\mu \mathrm{g} / \mathrm{g}_{\mathrm{dry}}$ weight ) and flavonols content (Q-gluc, Q-glu-gluc-rham, I-gluc, I-acet-gluc-gluc, expressed in $\mu \mathrm{g} / \mathrm{g}_{\mathrm{dry}}$ weight ) of corn mixtures and extrudates.

\begin{tabular}{|c|c|c|c|c|c|c|c|}
\hline Samples & $\begin{array}{l}\text { p-Coumaric } \\
\text { Acid }\end{array}$ & Ferulic Acid & Di-caff & Q-gluc & $\begin{array}{l}\text { Q-glu-gluc- } \\
\text { rham }\end{array}$ & I-gluc & $\begin{array}{l}\text { I-acet-gluc- } \\
\text { gluc }\end{array}$ \\
\hline \multicolumn{8}{|c|}{ Mixtures } \\
\hline $\mathrm{CM}$ & $64.75(0.21)^{\mathrm{aA}}$ & $42.86(0.04)^{\mathrm{aA}}$ & $58.61(0.06)^{\mathrm{aA}}$ & $-k$ & -h & $-\mathrm{i}$ & j \\
\hline $\mathrm{R} 4 \mathrm{M}$ & $61.95(0.05) \mathrm{bA}$ & $31.30(0.09)^{b B}$ & $44.47(0.03)$ bB & $18.29(0.03) \mathrm{gA}$ & $18.33(0.08) \mathrm{dB}$ & $19.96(0.08)^{\mathrm{eB}}$ & $17.62(0.12) \mathrm{gB}$ \\
\hline MDR4M & $61.56(0.03) \mathrm{dA}$ & $31.00(0.12) \mathrm{dB}$ & $44.22(0.51)$ bB & $16.35(0.07)^{j B}$ & $18.00(0.09)$ eB & $20.26(0.50){ }^{\mathrm{eB}}$ & $14.93(0.02){ }^{\mathrm{iB}}$ \\
\hline RMDR4M & $61.21(0.02) \mathrm{eA}$ & $30.83(0.22) \mathrm{eB}$ & $44.09(0.05) \mathrm{bB}$ & $18.27(0.04) \mathrm{gB}$ & $16.67(0.05) \mathrm{gB}$ & $18.29(0.45) \mathrm{gB}$ & $18.90(0.07)^{\mathrm{fA}}$ \\
\hline PPR4M & $61.76(0.06)^{\mathrm{cA}}$ & $31.13(0.05) \mathrm{cB}$ & $44.27(0.03)$ bB & $19.23(0.02)^{f B}$ & $16.62(0.02) \mathrm{gB}$ & $14.66(0.02)^{\mathrm{hB}}$ & $16.29(0.34) \mathrm{hB}$ \\
\hline CDR4M & $61.54(0.04) \mathrm{dA}$ & $30.82(0.34) \mathrm{eB}$ & $44.09(0.09)$ bB & $17.59(0.05)^{\mathrm{iB}}$ & $17.59(0.55)^{\mathrm{fB}}$ & $19.51(0.34)^{\mathrm{fB}}$ & $17.93(0.77) \mathrm{gB}$ \\
\hline $\mathrm{R} 8 \mathrm{M}$ & $59.55(0.13) \mathrm{fgA}$ & $29.49(0.13) \mathrm{fB}$ & $42.93(0.02) \mathrm{cdB}$ & $44.40(0.04)^{\mathrm{aA}}$ & $28.42(0.08) b B$ & $32.22(0.09){ }^{a B}$ & $27.77(0.08)^{a B}$ \\
\hline MDR8M & $59.56(0.02) \mathrm{fgA}$ & $29.22(0.07) \mathrm{gB}$ & $42.84(0.08) \mathrm{cdB}$ & $39.83(0.03)^{b A}$ & $31.67(0.04) \mathrm{aA}$ & $29.60(0.11)^{\mathrm{cA}}$ & $26.75(0.55) b B$ \\
\hline RMDR8M & $59.40(0.15) \mathrm{ghA}$ & $29.03(0.08) \mathrm{hB}$ & $42.74(0.02) \mathrm{dB}$ & $37.83(0.08)^{\mathrm{cA}}$ & $28.41(0.09)^{b B}$ & $29.60(0.05)^{c B}$ & $25.80(0.09) \mathrm{dB}$ \\
\hline PPR8M & $59.38(0.09)$ hA & $29.05(0.23) \mathrm{hB}$ & $43.34(0.84) \mathrm{cB}$ & $37.12(0.09) \mathrm{dA}$ & $31.59(0.03)^{a B}$ & $28.98(0.03) \mathrm{dB}$ & $26.39(0.05) \mathrm{cB}$ \\
\hline CDR8M & $59.59(0.03) \mathrm{fA}$ & $28.99(0.78) \mathrm{hB}$ & $42.70(0.15) \mathrm{dB}$ & $29.98(0.03){ }^{\mathrm{eB}}$ & $23.78(0.02){ }^{c B}$ & $30.31(0.02)^{\mathrm{bA}}$ & $24.44(0.03) \mathrm{eA}$ \\
\hline \multicolumn{8}{|c|}{ Extrudates } \\
\hline CE & $60.36(0.05)^{\mathrm{aB}}$ & $32.52(0.23) \mathrm{dB}$ & $46.79(0.40) \mathrm{eB}$ & $-k$ & j & $-g$ & j j \\
\hline R4E & $57.73(0.13)$ bB & $37.92(0.24)^{\mathrm{aA}}$ & $53.56(0.12)^{\mathrm{aA}}$ & $17.02(0.02){ }^{\mathrm{iB}}$ & $31.66(0.07){ }^{\mathrm{eA}}$ & $29.13(0.04)^{\mathrm{eA}}$ & $19.83(0.03) \mathrm{gA}$ \\
\hline MDR4E & $57.75(0.07)$ bB & $37.76(0.08)$ abA & $53.31(0.13)$ aA & $19.56(0.05) \mathrm{hA}$ & $27.11(0.55) \mathrm{hA}$ & $26.01(0.06)^{\mathrm{fA}}$ & $16.12(0.02){ }^{\mathrm{iA}}$ \\
\hline RMDR4E & $57.76(0.04){ }^{b B}$ & $37.78(0.08)$ abA & $53.26(0.22)$ abA & $23.59(0.23) \mathrm{gA}$ & $28.27(0.03) \mathrm{fgA}$ & $27.97(0.38)^{\mathrm{eA}}$ & $16.46(0.04){ }^{\mathrm{iB}}$ \\
\hline PPR4E & $57.48(0.11)^{\mathrm{cB}}$ & $37.81(0.07)$ aA & $53.31(0.33)$ aA & $25.96(0.34) \mathrm{eA}$ & $36.80(0.78) \mathrm{cA}$ & $31.47(0.78) \mathrm{dA}$ & $23.97(0.65)^{\mathrm{fA}}$ \\
\hline CDR4E & $57.36(0.15) \mathrm{dB}$ & $37.60(0.09) \mathrm{bA}$ & $52.71(0.66){ }^{b A}$ & $28.54(0.04) \mathrm{dA}$ & $27.82(0.03)$ ghA & $28.45(0.56)^{\mathrm{eA}}$ & $18.85(0.05)^{\mathrm{hA}}$ \\
\hline R8E & $55.35(0.04){ }^{\mathrm{fB}}$ & $36.62(0.13){ }^{\mathrm{cA}}$ & $51.91(0.07) \mathrm{cA}$ & $33.09(0.08)$ bB & $39.56(0.22) \mathrm{bA}$ & $40.05(0.22)^{\mathrm{bA}}$ & $34.30(0.67) \mathrm{bA}$ \\
\hline MDR8E & $55.37(0.08)$ efB & $36.65(0.22)^{\mathrm{cA}}$ & $51.63(0.23) \mathrm{cdA}$ & $25.35(0.06)^{f B}$ & $24.43(0.19){ }^{\mathrm{iB}}$ & $29.09(0.34)$ eA & $29.09(0.34)$ eA \\
\hline RMDR8E & $55.46(0.07){ }^{e B}$ & $36.73(0.31)$ cA & $51.50(0.22) \mathrm{cdA}$ & $25.09(0.45) \mathrm{fB}$ & $34.76(0.34) \mathrm{dA}$ & $34.70(0.05)^{\mathrm{cA}}$ & $34.70(0.05)^{\mathrm{cA}}$ \\
\hline PPR8E & $55.20(0.15)^{\mathrm{gB}}$ & $36.54(0.15){ }^{c A}$ & $51.17(0.07) \mathrm{dA}$ & $36.92(0.57)^{\mathrm{aA}}$ & $43.47(0.67)^{\mathrm{aA}}$ & $45.55(1.06)^{\mathrm{aA}}$ & $45.55(1.06)^{\mathrm{aA}}$ \\
\hline CDR8E & $55.41(0.02)$ efB & $36.60(0.06) \mathrm{cA}$ & $51.43(0.02) \mathrm{cdA}$ & $31.60(0.03) \mathrm{cA}$ & $28.81(0.94)^{\mathrm{fA}}$ & $25.38(0.02)^{\mathrm{fB}}$ & $25.38(0.02)^{f B}$ \\
\hline
\end{tabular}

Small different letters in superscript within column indicates significant changes between samples, by Fisher test $(p<0.05)$ comparing studied samples in mixtures or extrudates. Big different letter within column indicates significant changes between samples, by Fisher test $(p<0.05)$ comparing mixtures and extrudates. $\mathrm{R}$, rosehip; MDR, maltodextrin rosehip; RMDR, resistant maltodextrin rosehip; PPR, pea protein rosehip; CDR, cyclodextrin rosehip. 4, the concentration of $4 \%$ of rosehip preparation; 8 , the concentration of $8 \%$ of rosehip preparation. M, mixture; E, extrudate. Di-caff: Di-caffeic acid; Q-gluc: Quercetin-glucoside; Q-glu-gluc-rham: Quercetin-glucosyl-glucosylrhamnoside; I-gluc: Isorhamnetin-glucoside; I-acet-gluc-gluc: Isorhamnetin-acetyl-glucosyl. 
The phenolic acids from mixtures such as syringic acid and p-Coumaric acid were negatively influenced by the extrusion process $(p<0.05)$. However, in all samples with polymers, ferulic and Di-caffeic acids significantly increased their values through extrusion $(p<0.05)$ compared to the mixtures (Table 4 and Supplementary Tables S1 and S2). Total phenolic acids increase is shown in Figure 2a. Briefly, the total phenolic acids increase in extrusions ranged from $5.60 \%$ to $7.37 \%$ for CDR4E to RMDR8M samples, respectively.

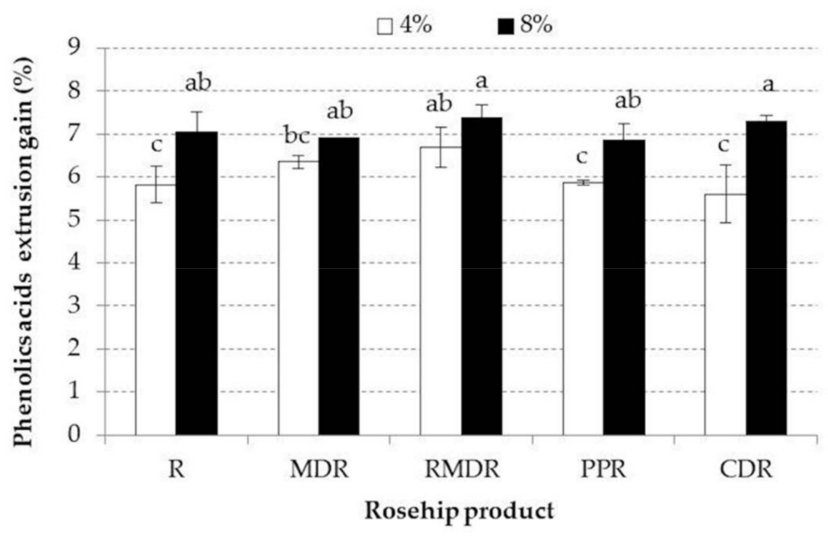

(a)

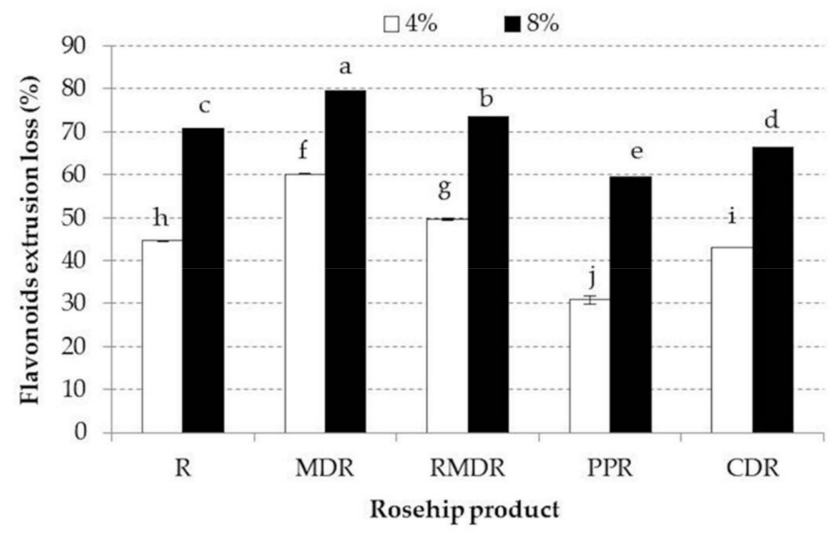

(b)

Figure 2. (a) Mean values and standard deviation of phenolic acids extrusion gain of samples enriched with different rosehip product at 4 and $8 \%$ concentration. (b) Mean values and standard deviation of phenolic acids extrusion loss of samples enriched with different rosehip products at 4 and $8 \%$ concentrations. Small different letters indicate significant changes between samples, by Fisher test $(p<0.05)$ for each analyzed parameter. R, rosehip; MDR, maltodextrin rosehip; RMDR, resistant maltodextrin rosehip; PPR, pea protein rosehip; CDR, cyclodextrin rosehip.

The extrusion effect on the phenolic content is still controversial and represents an open field to be further exploited. For instance, there are several studies that showed a negative correlation between the extrusion process and bioactive compounds. Pasqualone et al. [4] highlighted the extrusion could have a negative effect on the different groups of phenolic compounds. Anton et al. [45] showed that navy and red beans are rich sources of antioxidant activity and phenolic compounds; however, through extrusion, their amounts decreased by $10 \%$ and $17 \%$ for navy beans and $70 \%$ and $62 \%$ for red beans, respectively. The authors explained the decrease of bioactive compounds was due to extrusion temperature, moisture of the extrusion material, and a possible polymerization between phenolic acids and tannin, which could involve a decrease in the compounds' extractability, also reducing their antioxidant activities. In contrast, Arribas et al. [49] demonstrated that during an extrusion process, the phenolic groups are not affected to the same extend, highlighting that novel gluten-free expanded products based on pea flours increased their total phenolic content through extrusion.

Regarding flavonoids, one hydroxybenzoic acid (Di-Gallic acid) and ten flavonols were identified, as presented in Table 5. Adding rose hip increased the mixture's flavonoids amount, probably due to its rich flavonoid chemical composition, as previously shown $[7,50]$.

During extrusion, flavonols like Quercetin-acetyl-rhamnoside, Isorhamnetin-glucoside, and Procyanidin dimmer were lost, as presented in Figure 2b. PPR4E and PPR8E samples registered the smallest extrusion losses, being statistically different from the other samples $(p<0.05)$. For instance, the extrudates with $4 \%$ rosehip registered a $60 \%$ loss for the MDR4M sample, whereas PPR4E registered a loss of 39\% (Figure 2b). Regarding the MDR8M sample, the total flavonoids content was reduced by $80 \%$, whereas PPR8E registered a loss of $63 \%$. The results showed that during extrusion, PP highlighted the biggest flavonols protection, leading to minimal flavonols losses. The flavonoids decreasing amount during extrusion was also highlighted by Patil et al. [51] who showed that extrusion significantly reduced flavonoids in millet and sorghum flour. 
Table 5. Mean values (and standard deviations) of carotenoids content ( $\left.\mu \mathrm{g} / \mathrm{g}_{\text {dry weight }}\right)$ of corn mixtures and extrudates.

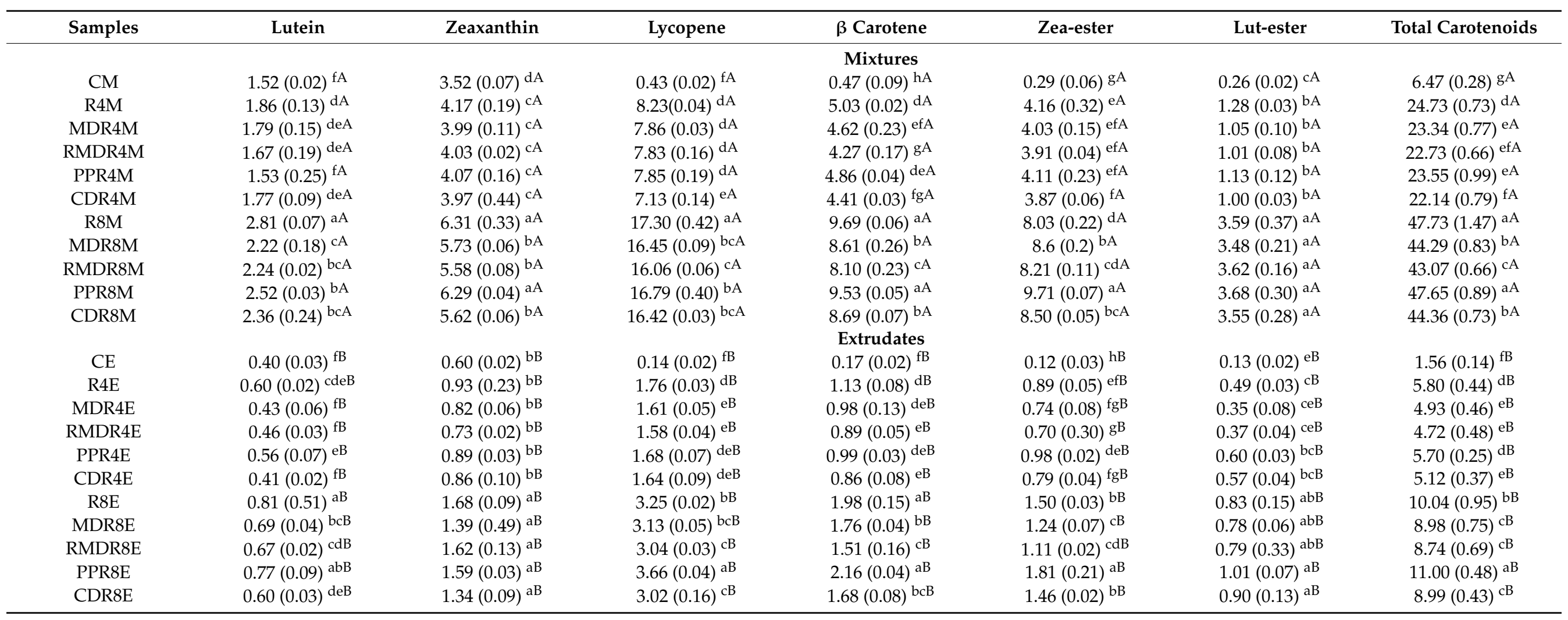

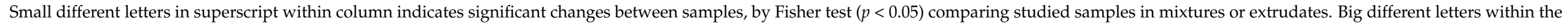

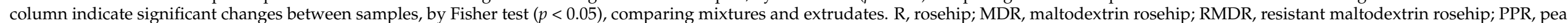
protein rosehip; CDR, cyclodextrin rosehip. 4 , the concentration of $4 \%$ of rosehip preparation; 8 , the concentration of $8 \%$ of rosehip preparation. $\mathrm{M}$, mixture; $\mathrm{E}$, extrudates. 


\subsubsection{Carotenoids Profile of Mixtures and Extrudates}

The increase of R4E and 8RE percentages increased the lutein, zeaxanthin, lycopene, $\beta$ Carotene, Zea-ester, and Lut-ester contents; again highlighting rose hip's substantial total carotenoid content. In this study, the rosehip showed a rich chemical composition of carotenoids, registering a total value of $208.35 \mu \mathrm{g} / \mathrm{g}$. The largest amounts were represented by lycopene, $\beta$ Carotene, Zea-ester, and Lut-ester as 78.95, 58.25, 44.54, and $14.32 \mu \mathrm{g} / \mathrm{g}$, respectively. The high level of carotenoids content in the rosehip was also mentioned by Al-Yafeai et al. [52] and Kazaz et al. [53].

Adding rose hip increased the mixture's content, leading to significant differences between samples with $4 \%$ and $8 \%$ addition, as presented in Table 5. Furthermore, Table 5 shows that the extrusion process leads to significant differences between mixtures and extrudates $(p<0.05)$. The carotenoids extrusion losses are illustrated in Figure 3a and show that samples with PPR8 registered the smallest carotenoids loss $(77.2 \%)$, whereas, samples with MDR, RMDR, and CDR registered similar high losses (80\%).

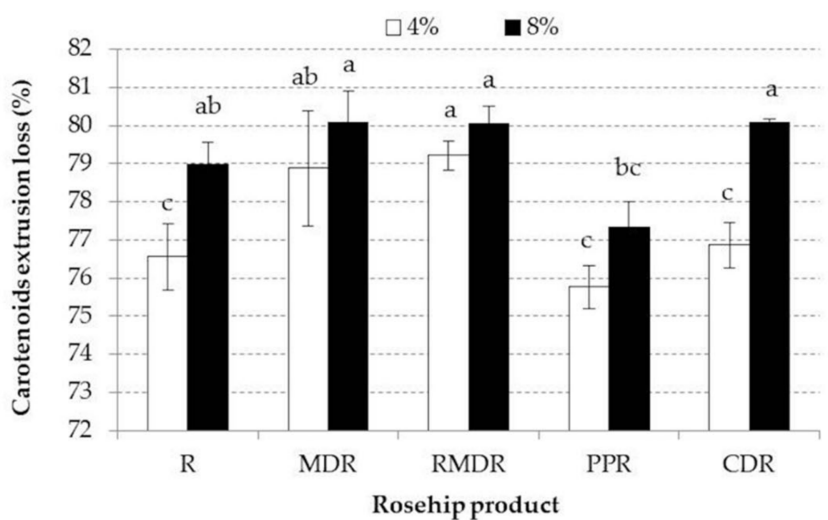

(a)

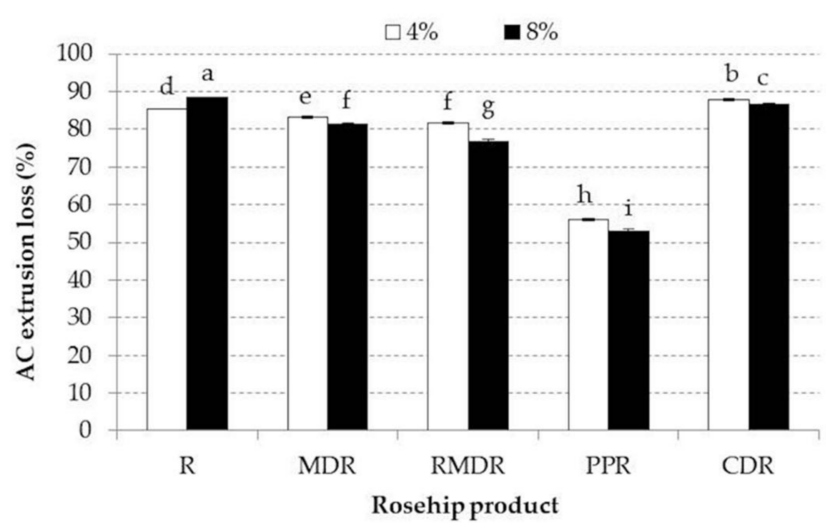

(b)

Figure 3. (a) Mean values and standard deviation of carotenoids extrusion loss of samples enriched with different rosehip products at 4 and $8 \%$ concentrations. (b) Mean values and standard deviation of antioxidant capacity (AC) extrusion loss of samples enriched with different rosehip products at 4 and $8 \%$ concentrations. Small different letters indicate significant changes between samples, by Fisher test $(p<0.05)$ for each analyzed parameter. R, rosehip; MDR, maltodextrin rosehip; RMDR, resistant maltodextrin rosehip; PPR, pea protein rosehip; CDR, cyclodextrin rosehip.

\subsubsection{Ascorbic and Dehydroascorbic Acids, Vitamin C, Folate, and Antioxidant Activity}

Adding rosehip in different percentages in mixtures had a positive influence on AA and DHAA, vitamin C, folate content, and AC, as presented in Table 6. In this study, the amount of AA, DHAA, vitamin C, folate, and AC in rosehip were 3.83, 1.39, 5.22, and $306 \mu \mathrm{g} / \mathrm{g}$, as well as $19.23 \mu \mathrm{gTE} / \mathrm{g}$, respectively. Roman et al. [5] showed values between $112.20 \mathrm{mg} / 100 \mathrm{~g}$ and $360.22 \mathrm{mg} / 100 \mathrm{~g}$ for the AA concentration in frozen rosehip pulp and explained the difference due to several factors such as altitude variations, harvesting period, ecological factors, and species. Furthermore, Mihaylova et al. [54] reported the AA content could be influenced by the harvesting time, the method of extraction, and the solvent:plant material ratio. Moreover, Georgieva et al. [55] reported a significantly larger amount of vitamin $C$ such as $110 \mathrm{mg} / 100 \mathrm{~g}$.

The AC mixtures values increased with rosehip addition, mainly because of its high antioxidant activity $(19.23 \mu \mathrm{g} \mathrm{TE} / \mathrm{g})$. A large body of literature emphasized the AC rosehip high content $[7,50,55]$, and justify it mainly due to the presence of flavonoids, according to Selahvarzian et al. [50]. Moreover, carotenoids compounds have been also associated with antioxidant activity, due to their radical scavenging properties of singlet molecular oxygen and peroxyl radicals, being considered efficient ROS scavengers [56]. Carotenoids were mentioned to be involved also in the reduction of the membrane structures oxidation and therefore, on the morbidity risk [51]. 
Table 6. Mean values (and standard deviations) of ascorbic acid (AA), dehydroascorbic acid (DHAA), vitamin C, folates, and antioxidant capacity. (AC) content ( $\mu \mathrm{g} / \mathrm{gdry}$ weight) of corn mixtures and extrudates.

\begin{tabular}{|c|c|c|c|c|c|}
\hline Samples & AA & DHAA & Vitamin C & Folates & AC (TEq) \\
\hline \multicolumn{6}{|c|}{ Mixtures } \\
\hline $\mathrm{CM}$ & $77.72(0.44) \mathrm{kA}$ & $126.60(0.37) \mathrm{kA}$ & $204.33(0.81)^{\mathrm{jA}}$ & $0.80(0.03)^{\mathrm{iA}}$ & $98.6(1.3) \mathrm{kA}$ \\
\hline $\mathrm{R} 4 \mathrm{M}$ & $401.34(0.07) \mathrm{eA}$ & $267.77(0.24) \mathrm{dA}$ & $669.11(0.31) \mathrm{dA}$ & $11.40(0.35)^{\mathrm{eA}}$ & $1480(6) \mathrm{cA}$ \\
\hline MDR4M & 315.95 (0.57) gA & $254.91(0.29)^{\mathrm{fA}}$ & $570.86(0.85)^{\mathrm{fA}}$ & $7.59(0.16) \mathrm{gA}$ & $920(3)^{\mathrm{fA}}$ \\
\hline RMDR4M & $300.67(0.27) \mathrm{hA}$ & $238.94(0.23) \mathrm{gA}$ & $539.61(0.50) \mathrm{gA}$ & $7.68(0.18)^{\mathrm{gA}}$ & $796(2)^{h A}$ \\
\hline PPR4M & $195.71(0.35) \mathrm{jA}$ & $219.24(0.33) \mathrm{iA}$ & $414.95(0.68) \mathrm{iA}$ & $6.75(0.29) \mathrm{hA}$ & $326(2) \mathrm{jA}$ \\
\hline CDR4M & $288.61(0.39){ }^{\mathrm{iA}}$ & $207.73(0.40){ }^{\mathrm{jA}}$ & $496.34(0.80) \mathrm{hA}$ & $8.49(0.28)^{\mathrm{fA}}$ & $1209(2) \mathrm{dA}$ \\
\hline R8M & $761.01(0.54)^{\mathrm{aA}}$ & $236.12(0.33) \mathrm{hA}$ & $997.13(0.88)^{\mathrm{aA}}$ & $20.47(0.25)^{\mathrm{aA}}$ & $2350.1(1.4)^{\mathrm{aA}}$ \\
\hline MDR8M & $503.70(0.66)^{\mathrm{cA}}$ & $303.88(0.09)^{\mathrm{aA}}$ & $807.59(0.75){ }^{b A}$ & $18.66(0.15)^{\mathrm{bA}}$ & $1054.4(0.9)^{\mathrm{eA}}$ \\
\hline RMDR8M & $441.54(0.30) \mathrm{dA}$ & $260.67(0.04)^{\mathrm{eA}}$ & $702.21(0.35)^{\mathrm{cA}}$ & $16.01(0.50)^{\mathrm{cA}}$ & 873 (6) gA \\
\hline PPR8M & $335.98(0.21) \mathrm{fA}$ & $272.00(0.53)^{b A}$ & $607.97(0.74) \mathrm{eA}$ & $14.45(0.26) \mathrm{dA}$ & $508(3)$ iA \\
\hline CDR8M & $537.142(0.43){ }^{b A}$ & $269.81(0.30) \mathrm{cA}$ & $806.95(0.73)$ bA & $19.03(0.36)^{\mathrm{bA}}$ & $1822(3)^{b A}$ \\
\hline \multicolumn{6}{|c|}{ Extrudates } \\
\hline $\mathrm{CE}$ & $35.12(0.41) \mathrm{hB}$ & $23.10(0.12) \mathrm{fB}$ & $58.22(0.52) \mathrm{hB}$ & $0.72(0.03) \mathrm{gA}$ & $11.8(1.3) \mathrm{hB}$ \\
\hline R4E & $55.50(0.20)^{\mathrm{bB}}$ & $33.30(0.23)^{\mathrm{aB}}$ & $88.80(0.43)^{b B}$ & $9.30(0.14) \mathrm{dB}$ & $216.8(1.4) \mathrm{cB}$ \\
\hline MDR4E & $39.41(0.51) \mathrm{gB}$ & $32.03(0.31) \mathrm{bB}$ & $71.44(0.83) \mathrm{gB}$ & $6.94(0.21)^{\mathrm{fA}}$ & $153(3)^{f B}$ \\
\hline RMDR4E & $50.43(0.31) \mathrm{dB}$ & $30.52(0.29) \mathrm{cdB}$ & $80.95(0.60) \mathrm{cdB}$ & $5.81(0.08){ }^{\mathrm{eB}}$ & $146.4(1.4)^{g B}$ \\
\hline PPR4E & $47.13(0.31) \mathrm{fB}$ & $32.78(0.53)^{\mathrm{aB}}$ & $79.91(0.84)$ defB & $5.82(0.27)^{\mathrm{eA}}$ & $144(2) \mathrm{gB}$ \\
\hline CDR4E & $48.79(0.30)$ eB & $30.95(0.28) \mathrm{cB}$ & $79.74(0.58)$ defB & $7.15(0.19) \mathrm{fB}$ & $148(3) \mathrm{gB}$ \\
\hline R8E & $85.50(0.30)^{\mathrm{aB}}$ & $33.32(0.15)^{\mathrm{aB}}$ & $118.82(0.45) \mathrm{aB}$ & $14.86(0.41)^{\mathrm{aB}}$ & $270.9(0.5)^{\mathrm{aB}}$ \\
\hline MDR8E & $50.76(0.34) \mathrm{dB}$ & $29.87(0.48) \mathrm{deB}$ & $80.63(0.82)^{\mathrm{cdeB}}$ & $10.06(0.19)^{c B}$ & $195.4(0.9)$ eB \\
\hline RMDR8E & $48.41(0.22){ }^{\mathrm{eB}}$ & $31.16(0.47)^{\mathrm{cB}}$ & 79.57 (0.68) efB & $10.35(0.19)^{\mathrm{cB}}$ & $202(2) \mathrm{dB}$ \\
\hline PPR8E & $51.79(0.66){ }^{\mathrm{cB}}$ & $29.99(0.21) \mathrm{deB}$ & $81.79(0.87){ }^{\mathrm{cB}}$ & $9.53(0.10) \mathrm{dB}$ & $238(3) b B$ \\
\hline CDR8E & $48.99(0.17) \mathrm{eB}$ & $29.60(0.33)^{\mathrm{eB}}$ & $78.58(0.50)^{f B}$ & $12.36(0.16)^{\mathrm{bB}}$ & $242(4) \mathrm{bB}$ \\
\hline
\end{tabular}

Small different letters in superscript within column indicates significant changes between samples, by Fisher test $(p<0.05)$, comparing studied samples in mixtures or extrudates. Big different letters within the column indicate significant changes between samples, by Fisher test $(p<0.05)$, comparing mixtures and extrudates. R, rosehip; MDR, maltodextrin rosehip; RMDR, resistant maltodextrin rosehip; PPR, pea protein rosehip; CDR, cyclodextrin rosehip. 4 , the concentration of $4 \%$ of rosehip preparation; 8 , the concentration of $8 \%$ of rosehip preparation. M, mixture; E, extrudates.

AC extrudates and vitamin $C$ values decrease during extrusion, even if polymers were used (Table 6, Figures $3 \mathrm{~b}$ and $4 \mathrm{a}$ ). The reduction of AC during the extrusion process was mentioned also by Anton et al. and Arribas [45,49] who explained it through a possible polymerization between phenolic acids and tannins ending with a decrease of the compounds extractability, and therefore, on the antioxidant activity. Furthermore, extrusion temperature and moisture of the extrusion material could also be factors that might be involved in the AC reduction during the extrusion process [48]. This is in line with Potter et al. [56] who showed that during extrusion of fruit powders to obtain snacks, Maillard Reaction Products with antioxidant activity could be inhibited by fruit powders. The same authors reported that during the fruit extrusion process, a decrease in the antioxidant activity ranging from $15 \%$ to $50 \%$, while the phenolic compound was not affected at all. This could be explained by the loss of antioxidants, other than the phenolic ones.

The samples folate content is presented in Table 6. The rosehip folate content $(306 \mu \mathrm{g} / \mathrm{g})$ influenced in a positive way the folate mixtures samples, being in concordance with Strålsjö et al. [57], who mentioned for rosehip a total value content ranging between 400 and $600 \mu \mathrm{g} / \mathrm{g}$ folate based on dry matter. With respect to folate extrudates, the highest values were registered by R8E $(14.86 \mu \mathrm{g} / \mathrm{g})$, meanwhile, the lowest values were recorded by CE $(0.72 \mu \mathrm{g} / \mathrm{g})$ and RMDR4E $(5.81 \mu \mathrm{g} / \mathrm{g})$ samples. The extrusion process led to a decrease in folate amount in all samples (Figure $4 \mathrm{~b}$ ). This could be explained by the key drivers involved in the folate amount decrease such as high temperature and low extrusion material moisture content, combined with screw speed, as mentioned by Gulati et al. [58]. 


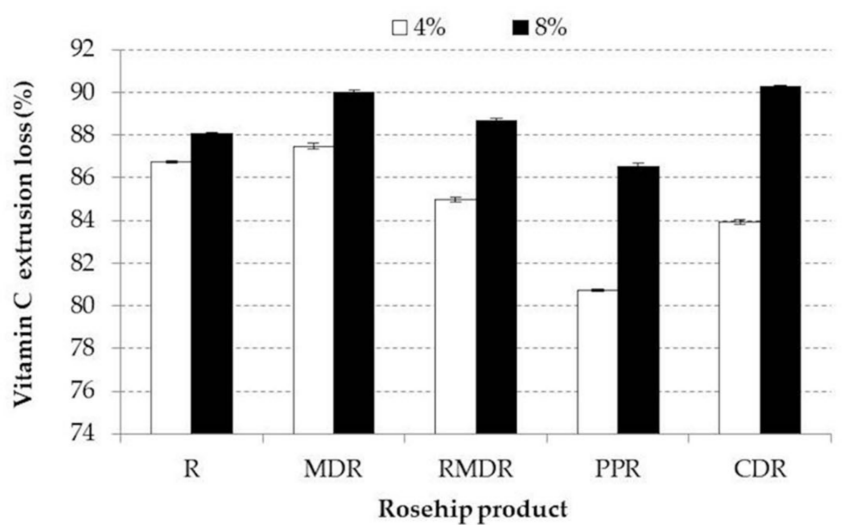

(a)

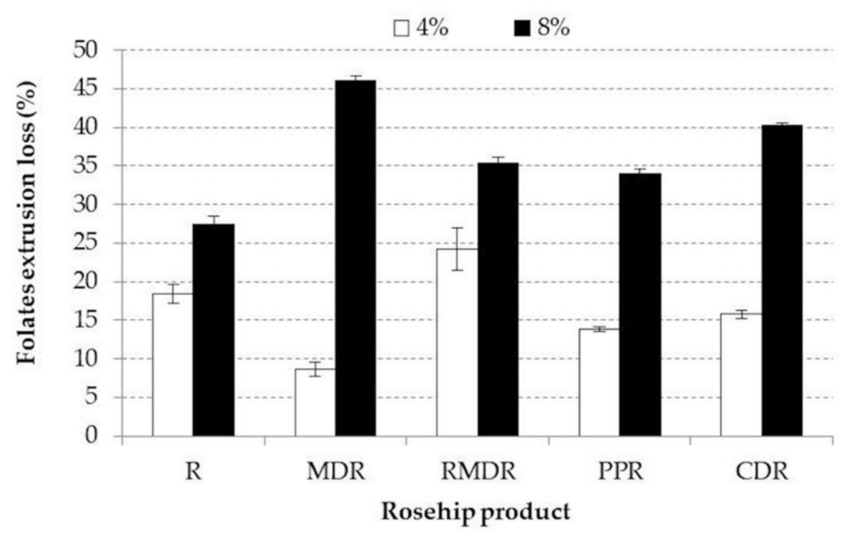

(b)

Figure 4. (a) Mean values and standard deviation of vitamin C extrusion loss of samples enriched with different rosehip products at 4 and $8 \%$ concentration. (b) Mean values and standard deviation of folates extrusion loss of samples enriched with different rosehip products 4 and $8 \%$ concentration. Small different letters indicate significant changes between samples, by Fisher test $(p<0.05)$ for each analyzed R, rosehip; MDR, maltodextrin rosehip; RMDR, resistant maltodextrin rosehip; PPR, pea protein rosehip; CDR, cyclodextrin rosehip.

The mixtures levels of AA and DHAA registered a linear increase with the addition of rosehip (Table 6), reaching the highest values for R8M and MDR8M samples, meanwhile vitamin $C$ content exhibited the highest values for the same samples: $997.13 \mu \mathrm{g} / \mathrm{g}$ and $807.59 \mu \mathrm{g} / \mathrm{g}$, respectively. The AA, DHAA, and vitamin C extruded contents were not protected against the extrusion process by the used biopolymers, probably due to the disintegration of wall material's crystalline structure during the extrusion process [13]. The decrease of vitamin C during extrusion was also mentioned by Gulatti et al. [58] and Singh et al. [59], who stated that vitamin $C$ is sensitive to heat and oxidation.

To better explain the relationship between vitamin C, AA, folates, total phenolic acids, total flavonoids, and total carotenoids, correlation statistical analyses were used. Positive strong Pearson's correlation coefficients $(0.9929,0.9927$, and $0.9907(p<0.05))$ were identified between folates, AA, vitamin C and AC mixtures and extrudates. Total flavonoids and total carotenoids also showed high positive Pearson's correlations of 0.9870 and $0.9615(p<0.05)$, respectively. Some authors have reported that the main contributing AC factor was vitamin C or AA $[60,61]$. However, other studies observed a high correlation between flavonoids and AC in grapefruit powders [62]. Likewise, Igual et al. [59] and Arilla et al. [63] found a significant correlation between the AA and TC content, like in the present study $(0.9846, p<0.05)$, probably because of the stabilizing effect of AA on carotenoids [64].

The nutrition labeling for foodstuffs from the Council [65] that the recommended daily allowance of folate is $200 \mu \mathrm{g}$. In line with this and regulation no. 1924/2006 of the European Parliament and of the Council of 20 December 2006 on nutrition and health claims made in foods [66], extrudates enrichment with rosehip are a food "high in folate." Moreover, the intake of $14 \mathrm{~g}$ of R8E or $36 \mathrm{~g}$ of RMDR4E (extrudates with the highest and the lowest folates content, respectively) can give the recommended daily allowances of folate. Likewise, in the case of vitamin C, the recommended daily allowance is $60 \mathrm{mg}$, so only R8E is a "source of vitamin C."

\subsubsection{Minerals Mixtures and Extrudates Content}

In this study, the biggest amounts of rosehip macrominerals were registered by $\mathrm{Ca}$ (Calcium), K (Potassium), and Mg (Magnesium) with 7367.09, 6785.77, and 1558.9 $\mu \mathrm{g} / \mathrm{g}$ values, meanwhile the micromineral values for Mn (Manganese), Fe (Iron) and Zn (Zinc) were $127.56,98.36$, and $20.56 \mu \mathrm{g} / \mathrm{g}$, respectively. 
According to the scientific literature, rosehip represents a rich source of minerals, such as $\mathrm{K}, \mathrm{Ca}, \mathrm{Mg}$, Na, $\mathrm{Mn}, \mathrm{Fe}$, and $\mathrm{Zn}$, as reported by a large body of literature $[53,54,67,68]$. For instance, Kazaz et al. [53] reported values of $1652.0 \mathrm{mg} / \mathrm{kg}$ for Na, $14,545.0 \mathrm{mg} / \mathrm{kg}$ for K, $8442.0 \mathrm{mg} / \mathrm{kg}$ for Ca, and $117.5 \mathrm{mg} / \mathrm{kg}$ for Fe. Furthermore, Mihaylova et al. [54] reported $73 \mathrm{mg} / \mathrm{kg}$ for Na, $7222 \mathrm{mg} / \mathrm{kg}$ for K, $3297 \mathrm{mg} / \mathrm{kg}$ Ca and $22 \mathrm{mg} / \mathrm{kg}$ for Fe, respectively. The differences between mineral composition could be influenced by harvest time, altitude, fruit size, ecological factors, variety, species [53], storage, and manipulation.

Adding rose hip increased the mineral content in the mixtures (Table 7), probably because rosehip contains high amounts of minerals. Furthermore, the extrusion process also increased the mineral content (Table 7). The highest extrudate macromineral content was reached by sample PPR8E, registering values of $572.25,637.40,1518.03$, and $257.61 \mu \mathrm{g} / \mathrm{g}$ for $\mathrm{Na}, \mathrm{Mg}$, K, and $\mathrm{Ca}$, respectively, and registered values of 23.02, 13.93, and $10.14 \mu \mathrm{g} / \mathrm{g}$ for microminerals $\mathrm{Fe}, \mathrm{Mn}$, and $\mathrm{Zn}$, respectively (Table 8 ). This could be explained by the fiber (crude fiber maximum of $10 \%$, according to the product specification sheet) and phenolic compounds of pea protein powder; and also by its initial ash content (maximum of $10 \%$ according to the product specification sheet).

Table 7. Macrominerals content $\left(\mu \mathrm{g} / \mathrm{g}_{\mathrm{dry}}\right.$ weight $)$ of corn mixtures and extrudates.

\begin{tabular}{|c|c|c|c|c|c|}
\hline Samples & $\mathrm{Na}$ & $\mathrm{Mg}$ & $\mathbf{K}$ & $\mathrm{Ca}$ & $\begin{array}{c}\text { Total } \\
\text { Macrominerals }\end{array}$ \\
\hline \multicolumn{6}{|c|}{ Mixtures } \\
\hline $\mathrm{CM}$ & $41.65(0.79)^{\mathrm{fB}}$ & $139.70(0.93)$ ев & $614.71(0.88) \mathrm{fB}$ & $61.26(0.89)$ eB & 857.32 (3.49) \\
\hline $\mathrm{R} 4 \mathrm{M}$ & $74.31(0.89) \mathrm{cB}$ & $240.02(0.89)_{\mathrm{cB}}$ & $964.11(0.65)^{\mathrm{cB}}$ & $108.80(0.77)^{\mathrm{cB}}$ & $1387.24(3.20)$ \\
\hline MDR4M & $67.94(0.80) \mathrm{deB}$ & $190.44(0.88) \mathrm{dB}$ & $884.90(0.39) \mathrm{dB}$ & $91.88(0.48) \mathrm{dB}$ & $1235.16(2.55)$ \\
\hline RMDR4M & $65.55(0.76) \mathrm{deB}$ & $189.93(0.57) \mathrm{dB}$ & $884.46(0.78) \mathrm{dB}$ & $90.59(0.57) \mathrm{dB}$ & $1230.53(2.68)$ \\
\hline PPR4M & $65.62(1.08){ }^{\mathrm{eB}}$ & $190.72(0.24) \mathrm{dB}$ & $885.96(0.81) \mathrm{dB}$ & $91.61(0.75) \mathrm{dB}$ & $1233.91(2.88)$ \\
\hline CDR4M & $68.31(1.10) \mathrm{dB}$ & $191.79(0.89) \mathrm{dB}$ & $871.58(0.96)$ eB & $91.96(0.79) \mathrm{dB}$ & $1223.64(3.74)$ \\
\hline $\mathrm{R} 8 \mathrm{M}$ & $96.79(0.43)^{\mathrm{aB}}$ & $421.78(0.77) \mathrm{aB}$ & $1399.21(0.44)^{\mathrm{aB}}$ & $190.13(0.65)^{a B}$ & 2107.91 (2.29) \\
\hline MDR8M & $94.01(0.27)^{\mathrm{bB}}$ & $402.15(0.88)_{b B}$ & $1325.50(0.77)^{b B}$ & $176.01(0.72)^{b B}$ & $1997.67(2.64)$ \\
\hline RMDR8M & $93.99(0.93) \mathrm{bB}$ & $400.00(0.79)_{\mathrm{bB}}$ & $1325.44(0.28) \mathrm{bB}$ & $175.10(0.80)^{b B}$ & $1994.53(2.80)$ \\
\hline PPR8M & $93.67(0.38)^{b B}$ & $402.04(0.97)_{\mathrm{bB}}$ & $1326.10(0.89)^{b B}$ & $175.56(0.19)^{b B}$ & $1997.37(2.43)$ \\
\hline CDR8M & $92.92(0.25)^{b B}$ & $\begin{array}{c}400.55(0.77) \mathrm{bB} \\
\text { Extrudates }\end{array}$ & $1325.59(0.85)^{\mathrm{bB}}$ & $175.22(0.72)^{b B}$ & 1994.28 (2.59) \\
\hline $\mathrm{CE}$ & $90.17(0.51)^{\mathrm{iA}}$ & $202.16(0.73)$ fA & $699.74(0.84) \mathrm{hA}$ & $119.60(0.72)^{\mathrm{gA}}$ & $1111.67(2.86)$ \\
\hline R4E & $339.08(0.57) \mathrm{gA}$ & $323.07(0.49) \mathrm{dA}$ & $1153.26(0.73)^{\mathrm{fA}}$ & $209.67(0.97)^{\mathrm{cA}}$ & $2025.08(2.76)$ \\
\hline MDR4E & $353.50(0.78)^{\mathrm{fA}}$ & $293.97(0.89) \mathrm{eA}$ & $984.21(0.58) \mathrm{gA}$ & $200.07(0.25)^{\mathrm{dA}}$ & $1831.75(2.50)$ \\
\hline RMDR4E & $394.11(0.38)$ eA & $297.75(0.88) \mathrm{eA}$ & $984.93(0.88) \mathrm{gA}$ & $172.80(0.78)^{\mathrm{fA}}$ & 1849.59 (2.92) \\
\hline PPR4E & $447.58(0.93) \mathrm{cA}$ & $328.11(0.73) \mathrm{dA}$ & $1159.71(0.78) \mathrm{eA}$ & $215.98(0.39)^{\mathrm{cA}}$ & $2151.38(2.83)$ \\
\hline CDR4E & $324.97(0.69) \mathrm{hA}$ & $289.06(0.34) \mathrm{eA}$ & $986.31(0.59) \mathrm{gA}$ & $189.99(0.89)^{\mathrm{eA}}$ & $1790.33(2.51)$ \\
\hline R8E & $393.57(0.99) \mathrm{eA}$ & $629.63(0.77)^{\mathrm{aA}}$ & $1510.00(0.82) \mathrm{bA}$ & $251.35(0.55)^{\mathrm{aA}}$ & $2784.55(3.13)$ \\
\hline MDR8E & $412.54(0.88) \mathrm{dA}$ & $603.05(0.99)$ bA & $1455.61(0.69) \mathrm{cA}$ & $239.05(0.93)^{\mathrm{bA}}$ & 2710.25 (3.49) \\
\hline RMDR8E & $455.16(1.09) \mathrm{bA}$ & $591.40(0.67)^{\mathrm{cA}}$ & $1451.61(0.73) \mathrm{dA}$ & $239.67(0.64)^{b A}$ & $2737.84(3.13)$ \\
\hline PPR8E & $572.25(0.88)^{\mathrm{aA}}$ & $637.40(0.63)^{\mathrm{aA}}$ & $1518.03(0.59)^{\mathrm{aA}}$ & $257.61(0.72)^{\mathrm{aA}}$ & $2985.29(2.82)$ \\
\hline CDR8E & $351.28(0.79)^{\mathrm{fA}}$ & $590.17(0.88)$ bcA & $1451.54(0.64)^{\mathrm{dA}}$ & $239.11(0.83)^{\mathrm{bA}}$ & $2632.10(3.14)$ \\
\hline
\end{tabular}

Small different letters in superscript within column indicates significant changes between samples, by Fisher test $(p<0.05)$, comparing studied samples in mixtures or extrudates. Big different letters within a column indicate significant changes between samples, by Fisher test $(p<0.05)$, comparing mixtures and extrudates. R, rosehip; MDR, maltodextrin rosehip; RMDR, resistant maltodextrin rosehip; PPR, pea protein rosehip; CDR, cyclodextrin rosehip. 4, the concentration of $4 \%$ of rosehip preparation; 8 , the concentration of $8 \%$ of rosehip preparation. M, mixture; E, extrudate.

Gulati et al. [58] showed that mineral bioavailability could be influenced by the raw material dietary fibers and phenolic compounds. For instance, phenolic compounds anionic groups can bind essential mineral elements and during an extrusion process are degraded or polymerized, leading to their decrease chelating properties. Furthermore, it seems that extrusion processes can influence the cell wall polysaccharides content, leading to higher amounts of soluble and insoluble fibers which improved mineral absorption. Botelho et al. [69] reported that rosehip could also be a source of condensed and hydrolyz- 
able tannins, from which oligomeric procyanidins were identified by Guimarães et al. [70], and ellagitannins reported by Fecka et al. [71]. Fetni et al. [72] also reported that rosehip methanol extract could have moderate levels of tannins. According to Rauf et al. [73], tannins could bind the mineral nutrient and therefore interfere in the digestion and absorption processes.

Table 8. Microminerals content $\left(\mu \mathrm{g} / \mathrm{g}_{\text {dry weight }}\right)$ of corn mixtures and extrudates.

\begin{tabular}{|c|c|c|c|c|c|c|c|c|}
\hline Samples & $\mathrm{Cr}$ & Mn & $\mathrm{Fe}$ & $\mathrm{Ni}$ & $\mathrm{Cu}$ & $\mathrm{Zn}$ & Se & $\begin{array}{c}\text { Total Mi- } \\
\text { crominerals }\end{array}$ \\
\hline \multicolumn{9}{|c|}{ Mixtures } \\
\hline $\mathrm{CM}$ & $0.25(0.04)$ eB & $1.35(0.29)^{\mathrm{fB}}$ & $14.58(0.60)^{\mathrm{dB}}$ & $0.27(0.03)^{\mathrm{eB}}$ & $0.86(0.04)^{\mathrm{cB}}$ & $4.26(0.12) \mathrm{deB}$ & $0.60(0.07)^{\mathrm{aA}}$ & 22.17 (1.19) \\
\hline $\mathrm{R} 4 \mathrm{M}$ & $0.97(0.03)^{\mathrm{cB}}$ & $5.95(0.12)^{\mathrm{cB}}$ & $16.47(0.55)^{\mathrm{cB}}$ & $0.54(0.04)^{\mathrm{cB}}$ & $1.06(0.10)^{b B}$ & $5.98(0.04)^{\mathrm{aB}}$ & $0.35(0.02)^{\mathrm{bA}}$ & $31.31(0.90)$ \\
\hline MDR4M & $0.76(0.04) \mathrm{dB}$ & $4.40(0.21)^{\mathrm{deB}}$ & $13.99(0.04)$ deB & $0.40(0.07) \mathrm{deB}$ & $0.82(0.04)^{c B}$ & $4.14(0.03)^{\mathrm{eB}}$ & $0.23(0.04)^{\text {cdeA }}$ & $24.74(0.47)$ \\
\hline RMDR4M & $0.79(0.05) \mathrm{dB}$ & $4.56(0.06) \mathrm{dE}$ & $14.10(0.14) \mathrm{deB}$ & $0.45(0.03) \mathrm{cdB}$ & $0.77(0.06)^{c B}$ & $4.36(0.05) \mathrm{dB}$ & $0.21(0.03) \operatorname{def} \mathrm{A}$ & $25.17(0.42)$ \\
\hline PPR4M & $0.69(0.07) \mathrm{dB}$ & $4.28(0.08) \mathrm{deB}$ & $13.92(0.06) \mathrm{deB}$ & $0.43(0.04)^{\mathrm{cdB}}$ & $0.80(0.03)^{c B}$ & $4.25(0.15) \mathrm{deB}$ & $0.27(0.02){ }^{c d A}$ & $24.64(0.45)$ \\
\hline CDR4M & $0.71(0.04) \mathrm{dB}$ & $4.17(0.98){ }^{\mathrm{eB}}$ & $13.83(0.08){ }^{e B}$ & $0.42(0.02)^{\mathrm{cdB}}$ & $0.83(0.21)^{\mathrm{cB}}$ & $4.32(0.03)^{\mathrm{deB}}$ & $0.30(0.06)^{\mathrm{bcA}}$ & $24.58(1.42)$ \\
\hline R8M & $1.51(0.04)^{a B}$ & $11.82(0.13)^{a B}$ & $19.68(0.07)^{\mathrm{aB}}$ & $0.87(0.06)^{\mathrm{aB}}$ & $1.35(0.05)^{\mathrm{aB}}$ & $5.02(0.20)^{b B}$ & $0.17(0.45)^{\text {efgA }}$ & $40.22(1.00)$ \\
\hline MDR8M & $1.22(0.05)^{\mathrm{bB}}$ & $10.33(0.16)^{\mathrm{bB}}$ & $17.39(0.24)^{\mathrm{bB}}$ & $0.75(0.11)^{\mathrm{abB}}$ & $1.23(0.02)^{\mathrm{abB}}$ & $4.76(0.07) \mathrm{cB}$ & $0.14(0.03)^{\mathrm{fgA}}$ & $36.36(0.68)$ \\
\hline RMDR8M & $1.25(0.03)^{b B}$ & $10.20(0.77)^{\mathrm{bB}}$ & $17.61(0.38)^{b B}$ & $0.77(0.02)^{\mathrm{abB}}$ & $1.26(0.51)^{\mathrm{aB}}$ & $4.67(0.06)^{\mathrm{cB}}$ & $0.11(0.02)^{g \mathrm{~A}}$ & $35.87(1.78)$ \\
\hline PPR8M & $1.19(0.23)^{b B}$ & $9.98(0.03)^{\mathrm{bB}}$ & $17.31(0.04)^{\mathrm{bB}}$ & $0.80(0.03)^{\mathrm{abB}}$ & $1.23(0.34)^{a b B}$ & $4.82(0.04)^{\mathrm{cB}}$ & $0.17(0.04)^{\text {efgA }}$ & $35.50(0.75)$ \\
\hline CDR8M & $1.11(0.16)^{b B}$ & $10.11(0.33)^{b B}$ & $15.51(0.14)^{\mathrm{bB}}$ & $0.74(0.05)^{\mathrm{bB}}$ & $1.38(0.71)^{\mathrm{aB}}$ & $4.77(0.03)^{\mathrm{cB}}$ & $0.12(0.34)^{\mathrm{gA}}$ & $33.74(1.76)$ \\
\hline \multicolumn{9}{|c|}{ Extrudates } \\
\hline CE & $0.92(0.03)^{\mathrm{fA}}$ & $1.94(0.06)^{\mathrm{hA}}$ & $16.91(0.11)^{\mathrm{eA}}$ & $0.75(0.04)^{\mathrm{fA}}$ & $1.74(0.07)^{\mathrm{cA}}$ & $6.88(0.14)^{\mathrm{hA}}$ & $0.00^{-\mathrm{B}}$ & $29.14(0.45)$ \\
\hline $\mathrm{R} 4 \mathrm{E}$ & $1.67(0.09)$ deA & $8.59(0.05) \mathrm{fA}$ & $18.11(0.31)^{\mathrm{dA}}$ & $1.01(0.03)^{\text {cdeA }}$ & $1.31(0.08) \mathrm{dA}$ & $7.83(0.08)$ efA & $0.00^{-\mathrm{B}}$ & $38.52(0.64)$ \\
\hline MDR4E & $1.53(0.02) \mathrm{eA}$ & $8.07(0.06)^{g A}$ & $18.39(0.23) \mathrm{dA}$ & $0.93(0.05)$ defA & $1.35(0.13) \mathrm{dA}$ & $7.48(0.23)^{\mathrm{fgA}}$ & $0.00^{-\mathrm{B}}$ & $37.75(0.72)$ \\
\hline RMDR4E & $1.56(0.07)^{\mathrm{eA}}$ & $8.05(0.03)^{g A}$ & $18.53(0.26)^{\mathrm{cdA}}$ & $0.86(0.03))^{\text {efA }}$ & $1.41(0.27)^{\mathrm{dA}}$ & $7.66(0.13)^{\text {efgA }}$ & $0.00^{-\mathrm{B}}$ & $38.07(0.79)$ \\
\hline PPR4E & $1.89(0.05)^{\mathrm{dA}}$ & $9.01(0.03)^{\mathrm{eA}}$ & $19.59(0.51)^{\mathrm{cA}}$ & $1.11(0.28)^{\mathrm{cdA}}$ & $1.90(0.23)^{b c A}$ & $8.04(0.16)^{\mathrm{eA}}$ & $0.00^{-\mathrm{B}}$ & $41.54(1.26)$ \\
\hline CDR4E & $1.52(0.26) \mathrm{eA}$ & $8.27(0.09)^{\mathrm{fgA}}$ & $18.43(0.59) \mathrm{dA}$ & $0.92(0.34) \operatorname{def} \mathrm{A}$ & $1.34(0.22) \mathrm{dA}$ & $7.40(0.03) \mathrm{gA}$ & $0.00^{-B}$ & $37.88(1.53)$ \\
\hline $\mathrm{R} 8 \mathrm{E}$ & $2.95(0.08)^{\mathrm{aA}}$ & $13.49(0.40)^{\mathrm{bA}}$ & $21.88(0.16)^{\mathrm{bA}}$ & $1.40(0.07)^{\mathrm{abA}}$ & $2.00(0.34)^{\mathrm{bA}}$ & $9.74(0.21)^{\mathrm{abA}}$ & $0.00^{-\mathrm{B}}$ & $51.46(1.26)$ \\
\hline MDR8E & $2.86(0.05)^{\mathrm{bA}}$ & $12.61(0.03) \mathrm{cA}$ & $21.00(0.34)^{\mathrm{bA}}$ & $1.22(0.05)^{\mathrm{bcA}}$ & $1.80(0.18)^{\mathrm{bcA}}$ & $9.17(0.08)^{\mathrm{cdA}}$ & $0.00^{-B}$ & $48.66(0.73)$ \\
\hline RMDR8E & $2.85(0.07)^{\mathrm{bA}}$ & $12.27(0.25)^{\mathrm{cdA}}$ & $21.19(0.52)^{\mathrm{bA}}$ & $1.17(0.08)^{\mathrm{bcA}}$ & $1.94(0.22)^{\mathrm{bA}}$ & $8.90(0.13)^{\mathrm{dA}}$ & $0.00^{-\mathrm{B}}$ & 48.32 (1.27) \\
\hline PPR8E & $3.31(0.03)^{\mathrm{bA}}$ & $13.93(0.06)^{\mathrm{aA}}$ & $23.02(0.78)^{\mathrm{aA}}$ & $1.59(0.06)^{\mathrm{aA}}$ & $2.45(0.13)^{\mathrm{aA}}$ & $10.14(0.13)^{\mathrm{aA}}$ & $0.00^{-\mathrm{B}}$ & 54.44 (1.19) \\
\hline CDR8E & $2.55(0.21)^{\mathrm{cA}}$ & $12.17(0.23) \mathrm{dA}$ & $21.13(0.13)^{\mathrm{bA}}$ & $1.16(0.24)^{\mathrm{cA}}$ & $1.85(0.89)^{\mathrm{bcA}}$ & $9.44(0.17){ }^{\mathrm{bcA}}$ & $0.00^{-\mathrm{B}}$ & 48.30 (1.87) \\
\hline
\end{tabular}

Small different letters in superscript within column indicates significant changes between samples, by Fisher test $(p<0.05)$, comparing studied samples in mixtures or extrudates. Big different letters within a column indicate significant changes between samples, by Fisher test $(p<0.05)$, comparing mixtures and extrudates. R, rosehip; MDR, maltodextrin rosehip; RMDR, resistant maltodextrin rosehip; PPR, pea protein rosehip; CDR, cyclodextrin rosehip. 4 , the concentration of $4 \%$ of rosehip preparation; 8 , the concentration of $8 \%$ of rosehip preparation. $\mathrm{M}$, mixture; E, extrudate.

Kamau et al. [74] reported the extrusion parameters such as temperature, extruder screw speeds, and extrusion material moisture could reduce the tannin content by $98 \%$. The strongest positive effect on different minerals, such as $\mathrm{Fe}$ and $\mathrm{Cu}$, was obtained using extrusion [75], leading to higher amounts. In white lupine, Fe $(4.10 \mathrm{mg} / 100 \mathrm{~g}$ dry weight) reached a value of $8.82 \mathrm{mg} / 100 \mathrm{~g}$ dry weight through extrusion, doubling its amount. Singh et al. [59] explained the enriched amounts of minerals through extrusion due to the reduction of antinutritional factors, such as condensed tannins and phytates. Moreover, the authors mentioned the chemical alteration of fiber could improve mineral absorption.

\section{Conclusions}

The addition of rosehip ( $R$. canina) powder led to significant changes in physicochemical characteristics of extrudates compared to a control sample. $x w, a w$, and $\rho_{b}$ showed significant decreases $(p<0.05)$ in all samples, whereas WSI and Hy increased significantly $(p<0.05)$. Extrudates with 4 or $8 \%$ rosehip encapsulated with pea protein registered the lowest WSI values, showing more sample stability. However, mixtures' optical properties, such as reddish color $a^{*}$ increased with increasing rose hip content, but in line with the color of these types of products. Nutritionally, PPR8E registered the highest content of AC, vitamin C, and total flavonoids content such as Quercetin-glucoside, Quercetinglucosyl-glucosyl-rhamnoside, Isorhamnetin-glucoside, and Isorhamnetin-acetyl-glucosylglucoside. PPR8E, R8E, and CDR8E exhibited the highest values of total carotenoid content, and macrominerals were identified in larger amounts in PPR8E, RMDR8E, and CDR8E.

To conclude, we can assess that the addition of $8 \%$ Rosa canina encapsulated with pea protein biopolymers could be successfully used in corn extrudates manufacturing. 
Supplementary Materials: The following are available online at https:/ / www.mdpi.com/article/ 10.3390/foods10102401/s1, Table S1. Mean values (and standard deviations) of phenolic acids ( $\mu \mathrm{g} / \mathrm{gdry}$ weight) of corn mixtures and extrudates, Table S2. Mean values (and standard deviations) of hydroxybenzoic acid (Di-Gallic acid) and flavanols content ( $\mu \mathrm{g} / \mathrm{gdry}$ weight) of corn mixtures and extrudates.

Author Contributions: Conceptualization, M.I. and M.S.C.; methodology, M.I., F.R., A.F., T.M, A.I.T. and M.S.C.; software, M.I.; validation, F.R., M.I., T.M. and D.C.V.; formal analysis, M.I., F.R., A.I.T., A.F. and T.M.; investigation, M.I., A.P., T.M., A.F., A.I.T. and M.S.C.; resources, J.M.-M., D.C.V. and P.G.-S.; data curation, M.I., A.I.T. and M.S.C.; writing-M.I., A.P. and M.S.C.; writing-review and editing, M.I., A.P., F.R., A.F. and M.S.C.; visualization, J.M.-M., D.C.V., A.P. and P.G.-S.; supervision, J.M.-M. and P.G.-S.; project administration, J.M.-M. and P.G.-S.; funding acquisition, D.C.V., A.F. and P.G.-S. All authors have read and agreed to the published version of the manuscript.

Funding: This work was funded by a grant from the Romanian Ministry of Education and Research, CNCS-UEFISCDI, project number PN-III-P4-ID-PCE-2020-2306, within PNCDI III, by funds from CASEE Fund for Incentives, project No: CASEE fund 2021-2 and by FDI 0013.

Data Availability Statement: The datasets generated for this study are available on request to the corresponding author.

Acknowledgments: The authors are grateful to Juan Vicente Baldo from the Food Technology Department, the Polytechnic University of Valencia for his technical support.

Conflicts of Interest: The authors declare no conflict of interest.

\section{References}

1. Luciano, F.B. Instrumental texture evaluation of extruded snack foods: A review Ciencia y Tecnología Alimentaria Sociedad Mexicana de Nutrición y Tecnología de Alimentos. Cienc. Tecnol. Aliment. 2007, 5, 245-251.

2. Shah, F.U.H.; Sharif, M.K.; Butt, M.S.; Shahid, M. Development of protein, dietary fiber, and micronutrient enriched extruded corn snacks. J. Texture Stud. 2017, 48, 221-230. [CrossRef] [PubMed]

3. Offiah, V.; Kontogiorgos, V.; Falade, K.O. Extrusion processing of raw food materials and by-products: A review. Crit. Rev. Food Sci. Nutr. 2019, 59, 979-2998. [CrossRef]

4. Pasqualone, A.; Costantini, M.; Coldea, T.E.; Summo, C. Use of Legumes in Extrusion Cooking: A Review. Foods 2020, 9, 958. [CrossRef]

5. Roman, I.; Stănilă, A.; Stănilă, S. Bioactive compounds and antioxidant activity of Rosa canina L. biotypes from spontaneous flora of Transylvania. Chem. Cent. J. 2013, 7, 1-10. [CrossRef] [PubMed]

6. Mármol, I.; Sánchez-De-Diego, C.; Jiménez-Moreno, N.; Ancín-Azpilicueta, C.; Rodríguez-Yoldi, M. Therapeutic applications of rose hips from different Rosa species. Int. J. Mol. Sci. 2017, 18, 1137. [CrossRef] [PubMed]

7. Tabaszewska, M.; Najgebauer-Lejko, D. The content of selected phytochemicals and in vitro antioxidant properties of rose hip (Rosa canina L.) tinctures. NFS J. 2020, 21, 50-56. [CrossRef]

8. Gruenwald, J.; Uebelhack, R.; Moré, M.I. Rosa canina-Rose hip pharmacological ingredients and molecular mechanics counteracting osteoarthritis-A systematic review. Phytomedicine 2019, 60, 1-10. [CrossRef] [PubMed]

9. Winther, K.; Campbell-Tofte, J.; Vinther Hansen, A.S. Bioactive ingredients of rose hips (Rosa canina L.) with special reference to antioxidative and anti-inflammatory properties: In vitro studies. Bot. Targets Ther. 2016, 6, 1-13. [CrossRef]

10. Stănilă, A.; Diaconeasa, Z.; Roman, I.; Sima, N.; Mănuțiu, D.; Roman, A.; Simona, R. Extraction and characterization of phenolic compounds from rose hip (Rosa canina L.) using liquid chromatography coupled with electrospray ionization-Mass spectrometry. Not. Bot. Horti Agrobot. Cluj-Napoca 2015, 43, 349-354. [CrossRef]

11. Lattanzio, F.; Greco, E.; Carretta, D.; Cervellati, R.; Govoni, P.; Speroni, E. In vivo anti-inflammatory effect of Rosa canina L. extract. J. Ethnopharmacol. 2011, 137, 880-885. [CrossRef]

12. Jiménez, S.; Gascón, S.; Luquin, A.; Laguna, M.; Ancin-Azpilicueta, C.; Rodríguez-Yoldi, M.J. Rosa canina extracts have antiproliferative and antioxidant effects on caco-2 human colon cancer. PLoS ONE 2016, 11, 1-14. [CrossRef]

13. Bamidele, O.P.; Emmambux, M.N. Encapsulation of bioactive compounds by 'extrusion' technologies: A review. Crit. Rev. Food Sci. Nutr. 2020, 1, 1-19. [CrossRef] [PubMed]

14. Wang, M.; Doi, T.; McClements, D.J. Encapsulation and controlled release of hydrophobic flavors using biopolymer-based microgel delivery systems: Sustained release of garlic flavor during simulated cooking. Food Res. Int. 2019, 119, 6-14. [CrossRef] [PubMed]

15. Shishir, M.R.I.; Xie, L.; Sun, C.; Zheng, X.; Chen, W. Advances in micro and nano-encapsulation of bioactive compounds using biopolymer and lipid-based transporters. Trends Food Sci. Technol. 2018, 78, 34-60. [CrossRef]

16. Tackenberg, M.W.; Krauss, R.; Schuchmann, H.P.; Kleinebudde, P. Encapsulation of orange terpenes investigating a plasticisation extrusion process. J. Microencapsul. 2015, 32, 408-417. [CrossRef] [PubMed] 
17. Chang, D.; Hayat, K.; Abbas, S.; Zhang, X. Ascorbic acid encapsulation in a glassy carbohydrate matrix via hot melt extrusion: Preparation and characterization. Food Sci. Technol. 2019, 39, 660-666. [CrossRef]

18. Ho, K.K.H.Y.; Schroën, K.; San Martín-González, M.F.; Berton-Carabin, C.C. Physicochemical stability of lycopene-loaded emulsions stabilized by plant or dairy proteins. Food Struct. 2017, 12, 34-42. [CrossRef]

19. Assadpour, E.; Jafari, S.M.; Maghsoudlou, Y. Evaluation of folic acid release from spray dried powder particles of pectin-whey protein nano-capsules. Int. J. Biol. Macromol. 2017, 95, 238-247. [CrossRef]

20. AOAC International. Official Methods of Analysis of Association of Official Analytical Chemists International. In Official Methods of Analysis of AOAC International; Horwitz, W., Latimer, G., Eds.; AOAC: Gaithersburg, MD, USA, 2006; ISBN 0935584773.

21. García-Segovia, P.; Igual, M.; Noguerol, A.T.; Martínez-Monzó, J. Use of insects and pea powder as alternative protein and mineral sources in extruded snacks. Eur. Food Res. Technol. 2020, 246, 703-712. [CrossRef]

22. Singh, N.; Smith, A.C. A comparison of wheat starch, whole wheat meal, and oat flour in the extrusion cooking process. J. Food Eng. 1997, 34, 15-32. [CrossRef]

23. Uribe-Wandurraga, Z.N.; Igual, M.; García-Segovia, P.; Martínez-Monzó, J. Influence of microalgae addition in formulation on colour, texture, and extrusion parameters of corn snacks. Food Sci. Technol. Int. 2020, 26, 685-695.

24. Robertson, J.A.; De Monredon, F.D.; Dysseler, P.; Guillon, F.; Amadò, R.; Thibault, J.F. Hydration properties of dietary fibre and resistant starch: A European collaborative study. LWT Food Sci. Technol. 2000, 33, 72-79.

25. Cai, Y.Z.; Corke, H. Production and Properties of Spray-dried Amaranthus Betacyanin Pigments. JFS 2000, 65, 1248-1252. [CrossRef]

26. Bouvier, J.M. Melt expansion in extrusion-cooking. Feed Technol. 1997, 1, 13-15.

27. Desrumaux, A.; Bouvier, J.M.; Burri, J. Corn grits particle size and distribution effects on the characteristics of expanded extrudates. J. Food Sci. 1998, 63, 857-863. [CrossRef]

28. Igual, M.; García-Segovia, P.; Martínez-Monzó, J. Effect of Acheta domesticus (house cricket) addition on protein content, colour, texture, and extrusion parameters of extruded products. J. Food Eng. 2020, 282, 110032. [CrossRef]

29. Hutchings, J.B. Food Color Mechanisms; Aspen Publishers Inc.: Gaithersburg, MD, USA, 1997; Chapter 11; pp. 453-592.

30. Igual, M.; Chiş, M.S.; Socaci, S.A.; Vodnar, D.C.V.; Ranga, F.; Martínez-Monzó, J.; García-Segovia, P. Effect of Medicago sativa Addition on Physicochemical, Nutritional and Functional Characteristics of Corn Extrudates. Foods 2021, 10, 1-21.

31. Szabo, K.; Dulf, F.V.; Teleky, B.E.; Eleni, P.; Boukouvalas, C.; Krokida, M.; Kapsalis, N.; Rusu, A.V.; Socol, C.T.; Vodnar, D.C.V. Evaluation of the Bioactive Compounds Found in Tomato Seed Oil and Tomato Peels Influenced by Industrial Heat Treatments. Foods 2021, 10, 110. [CrossRef]

32. Dulf, F.V.; Vodnar, D.C.V.; Dulf, E.H.; Toșa, M.I. Total Phenolic Contents, Antioxidant Activities, and Lipid Fractions from Berry Pomaces Obtained by Solid-State Fermentation of Two Sambucus Species with Aspergillus niger. J. Agric. Food Chem. 2015, 63, 3489-3500. [CrossRef] [PubMed]

33. Agudelo, C.; Igual, M.; Camacho, M.M.; Martínez-Navarrete, N. Effect of process technology on the nutritional, functional, and physical quality of grapefruit powder. Food Sci. Technol. Int. 2017, 23, 61-74. [CrossRef] [PubMed]

34. Mihăiescu, T.; Odagiu, A.; Gogi, G.; Mihăiescu, R.; Oroian, I. Heavy metals contamination of common blackberry in an area with a historical pollution-Copșa Mică (Romania). In Proceedings of the 17th International Multidisciplinary Scientific GeoConference SGEM, Vienna, Austria, 27-29 November 2017.

35. Senila, M.; Drolc, A.; Pintar, A.; Senila, L.; Levei, E. Validation and measurement uncertainty evaluation of the ICP-OES method for the multi-elemental determination of essential and nonessential elements from medicinal plants and their aqueous extracts. JAST 2014, 5, 1-9. [CrossRef]

36. Karkle, E.L.; Keller, L.; Dogan, H.; Alavi, S. Matrix transformation in fiber-added extruded products: Impact of different hydration regimens on texture, microstructure, and digestibility. J. Food Eng. 2012, 108, 171-182. [CrossRef]

37. Alam, M.S.; Kaur, J.; Khaira, H.; Gupta, K. Extrusion and Extruded Products: Changes in Quality Attributes as Affected by Extrusion Process Parameters: A Review. Crit. Rev. Food Sci. Nutr. 2016, 56, 445-473. [CrossRef]

38. Alam, M.R.; Scampicchio, M.; Angeli, S.; Ferrentino, G. Effect of hot melt extrusion on physical and functional properties of insect based extruded products. J. Food Eng. 2019, 259, 44-51. [CrossRef]

39. Gümüşay, Ö.A.; Şeker, M.; Sadıkoğlu, H. Response surface methodology for evaluation of the effects of screw speed, feed moisture, and xanthan gum level on functional and physical properties of corn half products. LWT 2019, 111, 622-631. [CrossRef]

40. Patil, R.T.; De Berrios, J.J.; Tang, J.; Pan, J.; Swanson, B. Physical characteristics of food extrudates-A review. In Proceedings of the ASAE (American Society of Agricultural Engineers) Annual International Meeting, Tampa, FL, USA, 17-20 July 2005.

41. Do Carmo, C.S.; Varela, P.; Poudroux, C.; Dessev, T.; Myhrer, K.; Rieder, A.; Zobel, H.; Sahlstrøm, S.; Knutsen, S.H. The impact of extrusion parameters on physicochemical, nutritional, and sensorial properties of expanded snacks from pea and oat fractions. LWT 2019, 112, 1-12.

42. Philipp, C.; Buckow, R.; Silcock, P.; Oey, I. Instrumental and sensory properties of pea protein-fortified extruded rice snacks. Int. Food Res. J. 2017, 102, 658-665. [CrossRef] [PubMed]

43. Cheng, E.M.; Alavi, S.; Pearson, T.; Agbisit, R. Mechanical-acoustic and sensory evaluations of cornstarch-whey protein isolate extrudates. J. Texture Stud. 2017, 38, 473-498. [CrossRef]

44. Azzollini, D.; Derossi, A.; Fogliano, V.; Lakemond, C.M.M.; Severini, C. Effects of formulation and process conditions on microstructure, texture, and digestibility of extruded insect-riched snacks. Innov. Food Sci. Emerg. Technol. 2018, 45, 344-353. [CrossRef] 
45. Anton, A.A.; Gary Fulcher, R.; Arntfield, S.D. Physical and nutritional impact of fortification of corn starch-based extruded snacks with common bean (Phaseolus vulgaris L.) flour: Effects of bean addition and extrusion cooking. Food Chem. 2009, 113, 989-996. [CrossRef]

46. Chanvrier, H.; Jakubczyk, E.; Gondek, E.; Gumy, J.C. Insights into the texture of extruded cereals: Structure and acoustic properties. Innovat. Food Sci. Emerg. Technol. 2014, 24, 61-68. [CrossRef]

47. Bodart, M.; de Peñaranda, R.; Deneyer, A.; Flamant, G. Photometry and colorimetry characterisation of materials in daylighting evaluation tools. Build. Environ. 2008, 43, 2046-2058. [CrossRef]

48. Dogan, H.; Karwe, M.V. Physicochemical Properties of Quinoa Extrudates. Food Sci. Tech. Int. 2003, 9, 101-114. [CrossRef]

49. Arribas, C.; Perreira, E.; Barros, L.; José Alves, M.; Calhelha, R.C.; Guillamón, E.; Pedrosa, M.M.; Ferreira, I.C.F.R. Healthy novel gluten-free formulations based on beans, carob fruit and rice: Extrusion effect on organic acids, tocopherols, phenolic compounds and bioactivity. Food Chem. 2019, 292, 304-313. [CrossRef]

50. Selahvarzian, A.; Alizadeh, A.; Baharvand, P.A.; Eldahshan, O.A.; Bahram, B.R. Medicinal Properties of Rosa canina L. Herb. Med. J. 2018, 3, 77-84.

51. Patil, S.S.; Varghese, E.; Rudra, S.G.; Kaur, C. Effect of Extrusion Processing on Phenolics, Flavonoids and Antioxidant Activity of Millets. Int. J. Food Ferment. Technol. 2016, 6, 1-8. [CrossRef]

52. Al-Yafeai, A.; Malarski, A.; Böhm, V. Characterization of carotenoids and vitamin E in R. rugosa and R. canina: Comparative analysis. Food Chem. 2018, 242, 435-442. [CrossRef] [PubMed]

53. Kazaz, S.; Baydar, H.; Erbas, S. Variations in Chemical Compositions of Rosa damascena Mill. and Rosa canina L. Fruits. Czech J. Food Sci. 2009, 27, 178-184. [CrossRef]

54. Mihaylova, D.; Vrancheva, R.; Petkova, N.; Ognyanov, M.; Desseva, I.; Ivanov, I.; Popova, N.; Popova, A. Carotenoids, tocopherols, organic acids, charbohydrate and mineral content in different medicinal plant extracts. Z. Naturforsch. Sect. C J. Biosci. 2018, 73, 439-448. [CrossRef]

55. Georgieva, S.; Angelov, G.; Boyadzhieva, S. Concentration of vitamin C and antioxidant activity of rosehip extracts. J. Chem. Technol. Metall. 2014, 49, 451-454.

56. Potter, R.; Stojceska, V.; Plunkett, A. The use of fruit powders in extruded snacks suitable for Children's diets. LWT Food Sci. Technol. 2013, 51, 537-544. [CrossRef]

57. Strålsjö, L.; Alklint, C.; Olsson, M.E.; Sjöhol, I. Total folate content and retention in rosehips (Rosa ssp.) after drying. J. Agric. Food Chem. 2003, 51, 4291-4295. [CrossRef]

58. Gulati, P.; Brahma, S.; Rose, D.J. Impacts of extrusion processing on nutritional components in cereals and legumes: Carbohydrates, proteins, lipids, vitamins, and minerals. Extrus. Cook. 2020, 1, 415-443.

59. Singh, S.; Gamlath, S.; Wakeling, L. Nutritional aspects of food extrusion: A review. Int. J. Food Sci. Technol. 2007, 42, 916-929. [CrossRef]

60. Igual, M.; García-Martínez, E.; Camacho, M.M.; Martínez-Navarrete, N. Stability of micronutrients and phytochemicals of grapefruit jam as affected by the obtention process. Food Sci. Technol. Int. 2016, 22, 203-212. [CrossRef]

61. Xu, G.; Liu, D.; Chen, J.; Ye, X.; Ma, Y.; Shi, J. Juice components and antioxidant capacity of citrus varieties cultivated in China. Food Chem. 2008, 106, 545-551. [CrossRef]

62. Igual, M.; Cebadera, L.; Cámara, R.M.; Agudelo, C.; Martínez-Navarrete, N.; Cámara, M. Novel ingredients based on grapefruit freeze-dried formulations: Nutritional and bioactive value. Foods 2019, 8, 506. [CrossRef] [PubMed]

63. Arilla, E.; García-Segovia, P.; Martínez-Monzó, J.; Codoñer-Franch, P.; Igual, M. Effect of Adding Resistant Maltodextrin to Pasteurized Orange Juice on Bioactive Compounds and Their Bioaccessibility. Foods 2021, 10, 1198. [CrossRef]

64. Choi, M.H.; Kim, G.H.; Lee, H.S. Effects of ascorbic acid retention on juice color and pigment stability in blood orange (Citrus sinensis) juice during refrigerated storage. Food Res. Int. 2002, 35, 753-759. [CrossRef]

65. Eur-Lex. Council Directive of 24 September 1990 on nutrition labeling for foodstuffs, (90/496/EEC). Off. J. Eur. Communities 2007, $276,40-44$.

66. Eur-Lex. Regulation (EC) No 1924/2006 of The European Parliament and of The Council of 20 December 2006 on nutrition and health claims made on foods. Off. J. Eur. Union 2006, 404, 9-25.

67. Demir, F.; Özcan, M. Chemical and technological properties of rose (Rosa canina L.) fruits grown wild in Turkey. J. Food Eng. 2001, 47, 333-336. [CrossRef]

68. Chrubasik, C.; Roufogalis, B.D.; Muller-Ladner, U.; Chrubasik, S. A Systematic Review on the Rosa canina CEffect and Efficacy Profiles. Phytother. Res. 2008, 22, 725-733. [CrossRef]

69. Botelho, G.; Canas, S.; Lameiras, J. Development of phenolic compounds encapsulation techniques as a major challenge for food industry and for health and nutrition fields. In Development of Phenolic Compounds Encapsulation Techniques; Elsevier Inc.: Amsterdam, The Netherlands, 2017; pp. 537-587.

70. Guimarães, R.; Barros, L.; Dueñas, M.; Cavalho, A.M.; Queiroz, M.J.R.P.; Santos-Buelga, C.; Ferreira, I.C.F.R. Characterisation of phenolic compounds in wild fruits from Northeastern Portugal. Food Chem. 2013, 141, 3721-3730. [CrossRef]

71. Fecka, I. Qualitative and quantitative determination of hydrolysable tannins and other polyphenols in herbal products from meadowsweet and dog rose. Phytochem. Anal. 2009, 20, 177-190. [CrossRef] [PubMed]

72. Fetni, S.; Bertella, N.; Ouahab, A. LC-DAD/ESI-MS/MS characterization of phenolic constituents in Rosa canina L. and its protective effect in cells. Biomed. Chromatogr. 2020, 34, 1-17. 
73. Rauf, A.; Imran, M.; Abu-Izneid, T.; Ul-Haq, I.; Patel, S.; Pan, X.; Naz, S.; Sanches Silvah, A.; Saeed, F.; Ansar Rasul Suleriaj, H. Proanthocyanidins: A comprehensive review. Biomed. Pharmacother. 2019, 116, 1-6. [CrossRef] [PubMed]

74. Kamau, E.H.; Nkhata, S.G.; Ayua, E.O. Extrusion and nixtamalization conditions influence the magnitude of change in the nutrients and bioactive components of cereals and legumes. Food Sci. Nutr. 2020, 8, 1753-1765. [CrossRef] [PubMed]

75. Suliburska, J.; Krejpcio, Z.; Lampart-Szczap, E.; Wójciak, R.W. Effect of fermentation and extrusion on the release of selected minerals from lupine grain preparations. Acta Sci. Pol. Technol. Aliment. 2008, 8, 87-96. 